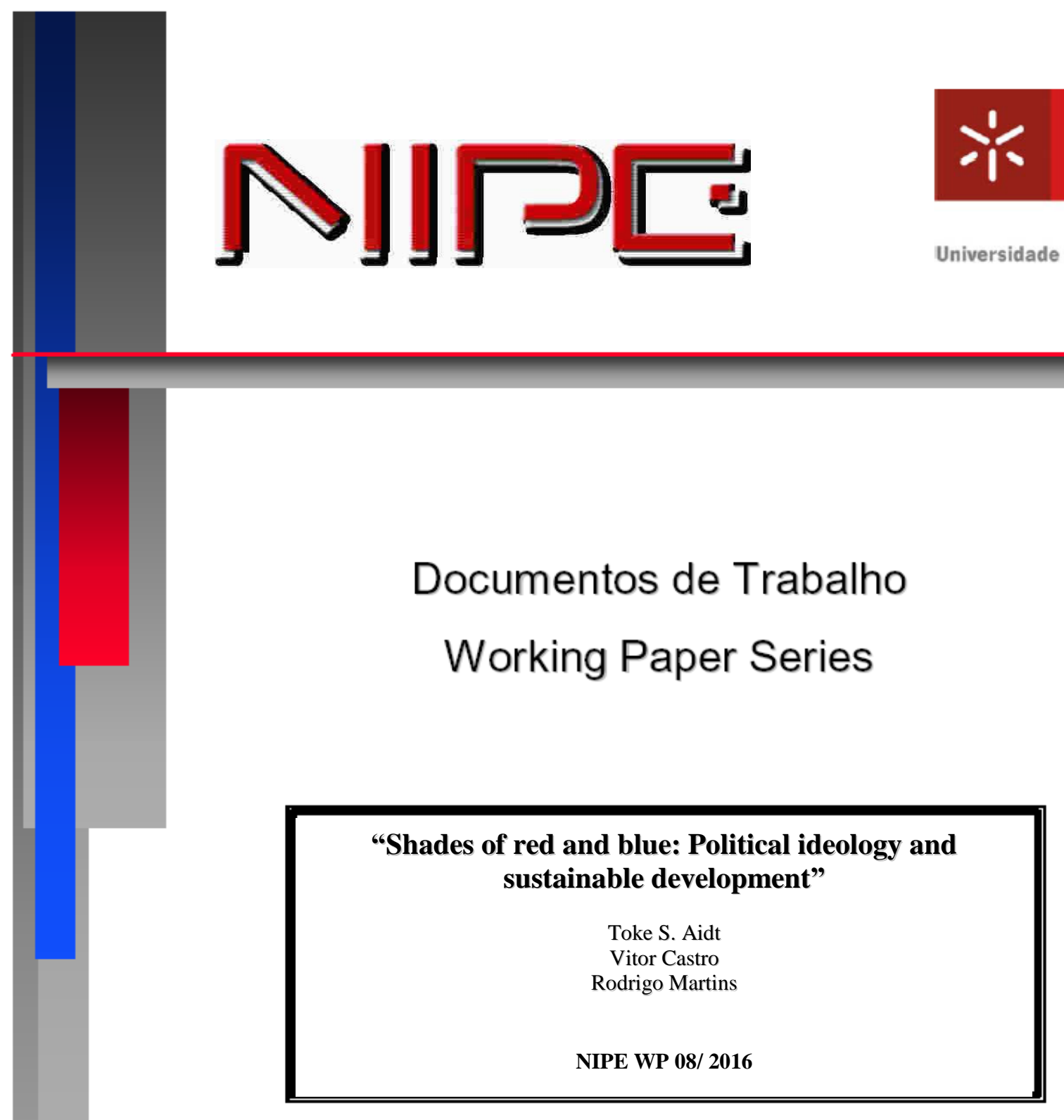

NÚCLEO DE INVESTIGAÇÃO EM POLÍTICAS ECONÓMICAS UNIVERSIDADE DO MINHO 


\section{"Shades of red and blue: Political ideology and sustainable development"}

Toke S. Aidt

Vitor Castro

Rodrigo Martins

\section{NIPE* WP 08/2016}

\section{URL:}

http://www.nipe.eeg.uminho.pt/

\section{C@MPETE 2020

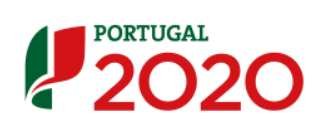

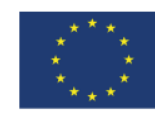

UNIĀO EUROPEIA

"This work was carried out within the funding with COMPETE reference no POCI-01-0145-FEDER-006683 (UID/ECO/03182/2013), with the FCT/MEC's (Fundação para a Ciência e a Tecnologia, I.P.) financial support through national funding and by the ERDF through the Operational Programme on "Competitiveness and Internationalization - COMPETE 2020 under the PT2020 Partnership Agreement» 


\title{
Shades of red and blue: Political ideology and sustainable development
}

\author{
Toke S Aidt* \\ University of Cambridge and Jesus College \\ Vitor Castro* \\ University of Coimbra and NIPE \\ Rodrigo Martins \\ University of Coimbra and GEMF
}

\begin{abstract}
We study the effect of political ideology on sustainable development, measured as investment in genuine wealth, in a dynamic panel of 79 countries between 1981 and 2013. We find that a switch from a left-wing or centrist government to a right-wing government has a robust positive and statistically significant effect on investment in genuine wealth. We find no evidence of opportunistic cycles in these investments.
\end{abstract}

JEL: C23, D72, I31, O15.

Keywords: Sustainable development, Political ideology; Genuine investment.

\footnotetext{
* Faculty of Economics, University of Cambridge, CB3 9DD Cambridge, U.K. Phone: +44(0) 1223 335231; Fax: +44(0) 1223 335375. E-mail: tsa23@econ.cam.ac.uk

* Faculty of Economics, University of Coimbra, Av. Dias da Silva 165, 3004-512 Coimbra, Portugal. University of Minho, Economic Policies Research Unit (NIPE), Campus of Gualtar, 4710-057 Braga, Portugal. Phone: +351 239 790543; Fax: +351 239 790514; E-mail: vcastro@ @e.uc.pt

- Faculty of Economics, University of Coimbra, Av. Dias da Silva 165, 3004-512 Coimbra, Portugal. Group for Monetary and Fiscal Studies (GEMF), Av. Dias da Silva 165, 3004-512 Coimbra, Portugal. Phone: +351 239 790543; Fax: +351 239 790514; E-mail: rodrigom@ @e.uc.pt
} 


\section{Introduction}

The purpose of this paper is to study the effect of political ideology on sustainable development. The value of doing this is two-fold. First, in the face of important social challenges, ranging from climate change to aging populations, the question of sustainable development has become a top priority for many observers and policy makers (Arrow et al., 2004). Sustainability is closely related to investment in a society's capital stocks broadly conceived to include manufactured, human, and natural capital and referred to as genuine wealth. A country that is running down its genuine wealth is on an unsustainable development path and will experience falling welfare levels even if in the short-term its GDP per capita is raising. More precisely, intertemporal social welfare of a society is increasing if and only net investment in its genuine wealth is positive (Dasgupta and Mäler, 2000; Arrow et al., 2003). Since these investments can, in principle, be measured (Atkinson and Hamilton, 2003; World Bank, 2006), it is possible to study empirically the determinants of sustainable development and doing so is of first order importance (Dasgupta, 2010). Second, sustainability is intrinsically linked to issues of governance. As noted, sustainable development requires investment in society's capital assets and decisions on these investments are the outcome of a political decision making process. Aspects of this nexus have been investigated previously. Aidt (2011), for example, shows that corruption has a robust negative influence on sustainable development, while legal institutions that govern the way disputes are settled make little difference. Aidt and Veiga (2016) study the link between political institutions that define the general framework that governs decision making in a society and find a positive link between institutional quality and sustainable development. We add to this literature by studying whether short-term fluctuations in 
the political ideology of the government (measured on a left-right scale) induce fluctuations in genuine investment.

Specifically, we use a panel of 79 countries between 1981 and 2013 to study the relationship between political ideology and growth in genuine investment. We find that right-wing governments are associated with improvements in genuine investment while genuine wealth tends to be run down under left-wing governments.

The rest of the paper is organised as follows. Section 2 provides an introduction to the theory underlying using genuine investment as an index of sustainable development and develops hypothesises linking investment in genuine wealth to the partisan cycle. Section 3 presents the data and the econometric approach. Section 4 presents the main results related to political ideology and genuine investment. Section 5 investigates the interplay between the years a party has been in power, political ideology and genuine investment. Section 6 offers a broader discussion of the results.

\section{Theoretical background and hypothesises}

The World Commission (1997) loosely defines sustainable development as a current economic path that does not compromise the well-being of future generations. Following Arrow et al. (2004), we adopt a more specific definition and say that a society is on a sustainable path if the present discounted value of the social welfare attained at each future date (its intertemporal social welfare) is not decreasing along that path. The advantage of this definition is that it puts the concept on a sound welfare theoretical foundation ${ }^{1}$ and that it offers an operational bridge between theory and

\footnotetext{
${ }^{1}$ In a recent survey, Fleurbaey (2009) highlights three main approaches to the measurement of social welfare: adjusted GDP, happiness indices, and the Human Development Index based on A. K. Sen's
} 
empirical measurement. Dasgupta and Mäler (2000) proved that at society's intertemporal social welfare at time $t$ is increasing if, and only if, the net investment in its genuine wealth is positive (see also Dasgupta, 2001; 2010). Genuine wealth refers to the society's capital stocks broadly defined to include manufactured, human and natural capital and genuine investment is simply the additions to the various stocks valued at appropriately defined shadow prices. We return to the matter of how genuine investment can be measured empirically in the next section, but before we do that we discuss why partisan politics and elections, more generally, may induce cycles in genuine investment.

Whether a society at a given point in time moves along a sustainable development path or not is determined by the institutions that govern investment in genuine wealth. In democratic societies, these investment choices are made by elected politicians and the political parties they represent. The ideological position of the ruling government is likely to influence the scale, timing and composition of these investments. Elections provide citizens with a mechanism for selecting new governments and, as a consequence, parties with different ideologies gain and lose control of government at election time. Our hypothesis is that this induces partisan cycles in genuine savings and that a society over time may move on and off a sustainable economic path. The classical works by Hibbs $(1977,1987)$ and Alesina (1987) have shown how partisan cycles can emerge in macroeconomic aggregates because left-party governments are more inclined than right-party ones to pursue expansive policies designed to yield lower unemployment and higher growth, but running the risk of extra inflation. A more recent literature establishes how party ideology influences the size and scope of government with left-wing governments being 
more expansionary than right-wing governments (Pickering and Rockey, 2011; 2013) while right-wing governments are more willing to deregulate labour markets (Bjørnskov and Potrafke, 2012; 2013) and to promote deregulation of the energy, transport and communication industries (Potrafke, 2010). ${ }^{2}$

We conjecture that the fiscal conservatism of right-wing parties and their greater willingness to deregulate the economy will positively influence investment into manufactured capital and concentrate public spending on provision of merit goods like education at the expense of welfare programmes. The later effect is reinforced by the findings of Kauder and Potrafke (2013) that right-wing parties are more willing to mobilise private funds to co-fund higher education. With respect to natural capital which is preserved or accumulated through farsighted exploration of natural resources and through environmental regulation, it is less clear if right-wing parties will support policies that preserve and build-up the stock of natural capital to a larger or smaller extend than left-wing parties. Right-wing parties' general willingness to deregulate market may, for example, spill over into a specific unwillingness to regulate externalities. It is, therefore, not a priori clear what the nature of the partisan cycle might be and the matter must be considered an open empirical question.

Besides setting the stage for partisan cycles, the election calendar may also induce opportunistic cycles. According to the literature on opportunistic political business cycles, in their quest for votes, parties from across the ideological spectrum may use the fiscal and monetary tools available to them to expand economic activity before elections and to calm the economy subsequently to reduce inflationary pressures. $^{3}$ A by-product of this could be a political business cycle in genuine

\footnotetext{
${ }^{2}$ See also Reed (2006), Imbeau et al. (2001), and Frederiksson et al. (2013).

${ }^{3}$ The theoretical foundation for the opportunistic political business cycle was laid by Nordhaus (1975) and integrated into rational expectations models by Rogoff and Sibert (1988) and Rogoff (1990). The
} 
investment. For example, the short-termism in macroeconomic management induced by such opportunistic behaviour may divert attention away from investment in the economy's capital stocks and towards current consumption and in that way create a dip in genuine investment around elections. However, whether the unintended consequences of opportunistic attempts to manipulate the macroeconomy are sufficiently strong to create a political business cycle in genuine investment must also be considered an open empirical question.

\section{Data and Econometric Specification}

To investigate the interplay between ideology, elections and genuine investment, we use an unbalanced panel dataset of 79 countries between 1981 and 2013. To be included in the sample, a country must have regular elections over the relevant period. ${ }^{4}$ The countries in the sample are listed in the note to Table 1. Our sample includes countries from Europe, the Americas, Africa, Oceania, the Middle East, and Asia.

In order to test for partisan cycles in genuine investment, we need two primary inputs. Firstly, we need empirical estimates of genuine investment across time and space. The World Bank, as part of the World Development Indicators (WDI), publishes those estimates (in percentage of gross national income - GNI). Their estimates of

literature has recently been surveyed by Dubois (2016). Empirical studies suggest that favorable economic conditions in the lead-up to an election do benefit the incumbent government (Hibbs, 2006).

${ }^{4}$ Specifically, we use the Legislative and Executive Indices of Electoral Competitiveness from the Database of Political Institutions (DPI) which scores countries on a 1 to 7 scale. We excluded countries with a value lower than 6 . This means that we include countries (during periods) in which they had competitive elections where multiple parties did win seats. A score of 6 indicates that the largest party received more than $75 \%$ of the seats while a score of 7 indicates that it won less than that. 
genuine investment are obtained by making four adjustments to gross national savings. ${ }^{5}$ The first adjustment is to deduct an estimate of consumption of fixed capital to account for depreciation of manufactured capital. The second adjustment is to add an estimate of investment in human capital. Public expenditure on education is used as a proxy for this. The third adjustment relates to the social cost of environmental pollution. ${ }^{6}$ The fourth adjustment is also environmentally motivated. It seeks to account for energy depletion, mineral depletion, and net forest depletion by subtracting an estimate of the relevant resource rents from net national savings. ${ }^{7}$ The result of these adjustments of gross national savings provides a rough estimate of genuine investment in terms of the percentage of gross national income (GNI). We follow Arrow et al. (2003) and convert this into an estimate of growth in genuine wealth per capita (GWgrowth) by multiplying genuine investment as percentage of GNI by a presumed GNI-wealth ratio ${ }^{8}$ and by subtracting the population growth rate from that product.

Secondly, we need empirical measures of political ideology. Constructing indicators of government ideology is complicated by the fact that there exist substantial differences in party and parliamentary systems across the countries in our sample and by the fact that coalition governments consisting of two or more parties with different ideologies can be coded in different ways. We use the classification (EXECRLC)

\footnotetext{
${ }^{5}$ For details on how it is computed see Arrow el al. (2003). The WDI use the term "adjusted net savings" to describe what we refer as "genuine investment".

${ }^{6}$ It has two parts. The first is designed to capture the cost of global warming. An estimate of the social cost of carbon dioxide emissions is subtracted from national savings, with the assumption that the average social cost of a tonne of carbon is US\$30. The second part is designed to capture the impact of local environmental degradation. The World Bank makes a financial deduction for an estimate of the health damages due to urban air pollution (particulate emissions) from gross savings.

${ }^{7}$ These rents are calculated as the market price of the resource minus average extraction cost for the two non-renewable resources (energy and mineral depletion). For renewable forest resources, the rent is estimated as the market price per unit of harvest in excess of the natural regeneration rate.

${ }^{8}$ The ratios we use are 0.2 for industrialized countries and 0.15 for developing and oil-rich countries.
} 
proposed in the Database of Political Institutions (DPI) to characterize party ideology. ${ }^{9}$ The DPI divides parties into three groups based on an evaluation of a party's orientation with respect to economic policy. We define the corresponding indicator variables, Right, Left or Center. For single party majority governments, the indictor variable corresponding to its ideology takes the value one in years during which the party rules a given country. For coalition governments, the DPI classifies a coalition government as having the ideology of the largest coalition partner. The group of right-wing parties includes conservative, Christian democratic, and other right-wing parties; the group of left-wing parities includes communist, socialist, social democratic, and other left-wing parties; and the group of Center includes parties defined as centrists or which party position can best be described as centrist. ${ }^{10}$

To estimate the impact of the political ideology on genuine investment, we consider the following dynamic panel specification:

$$
\text { GWgrowth }_{i t}=\rho G \text { Growth }_{i t-1}+\boldsymbol{\alpha I d e o l o g}_{i t}+\boldsymbol{\beta} \boldsymbol{P o l}_{i t}+\boldsymbol{\gamma} \boldsymbol{E c o n}_{i t}+\gamma_{t}+v_{i}+e_{i t}
$$

where $i=1, \ldots, 79$ and $t=1981, \ldots, 2013$. The coefficient on the first lag of the dependent variable $(\rho)$ measures persistence in the growth rate of genuine wealth per capita (GWgrowth). The error structure includes a country specific effect $v_{i}$, a time fixed effect $\gamma_{t}$ and the idiosyncratic error term $e_{i t}$. The vector Ideology includes the indicator variables for the ideology of the government. The vectors Pol and Econ include,

\footnotetext{
${ }^{9}$ For the subset of OECD countries and for individual countries (such as the USA and Canada) more refined classifications of party ideology exist (see Bjørnskov (2005, 2008); Bjørnskov and Potrafke (2012, 2013).

${ }^{10}$ For further information on how the party classification is constructed see the DPI codebook (Keefer, 2012).
} 
respectively, political and economic control variables. Table 1 describes these variables in detail. We include two main political control variables in all specifications. The variable Election year controls for the timing of elections and enables us to distinguish partisan cycles from election cycles. The variable Party tenure records the number of years that the government party has been in power. In some specifications, we replace this with the variable Leader tenure which records the number of years that the current party leader has been in control. This enables us to separate the effect of the political ideology of the government from the effect of length in government. In some specifications, we also include the Polity IV index which captures the quality of political institutions. This allows us to isolate the short to medium term effect of political ideology on sustainability from the potential long-run effect of changes in underlying political institutions.

The theory underlying the use of genuine investment as an index of sustainability requires us to control for the capital stocks and for the shadow prices associated with those stocks. Direct measures of the capital stocks are hard to come by and we use the following imperfect proxies: Government consumption, Years of schooling, GDP per capita and Urban population ratio. It is even more difficult to find proxies for the relevant shadow prices. We note, however, that world market prices can in many cases be used as shadow prices for internationally traded goods. This suggests that we can use imports plus exports as a percentage of GDP (Trade openness) to proxy for this.

\section{[Insert Table 1 around here]}


The lagged dependent variable is correlated with the error term even if the latter is not serially correlated due to country-specific fixed effects $v_{i}$, This implies that Random or Fixed Effects estimates are biased and inconsistent (Baltagi, 2008). Estimators that take into account that bias include: (i) bias-corrected estimators; and (ii) instrumental variables estimators. Bias-corrected estimators, like the one proposed by Bruno (2005a, b) - the bias-corrected least squares dummy variable estimator (LSDVC) for dynamic panel data models - are suitable when the number of individuals $(N)$ is small (and $T$ is not large enough). Although $T$ is not large in this study, the number of individuals cannot be considered small $(N=82)$. Hence, this estimator may not be the most suitable choice for us and we estimate equation (1) with an instrumental variables estimator.

According to the large sample properties of the generalized method of moments (GMM), the dynamic estimator proposed by Arellano and Bond (1991) is adequate when there is a clear dominance of cross sections over time periods in the sample. This is what happens in our panel. Taking first differences of equation (1), levels of the explanatory variables can be used as instruments to avoid correlation between lagged dependent variable and the country-specific effects. Arellano and Bond (1991) also proposed a variant of the GMM estimator, namely the two-step estimator, which utilizes the estimated residuals in order to construct a consistent variance-covariance matrix of the moment conditions. Although the two-step estimator is asymptotically more efficient than the one-step estimator and relaxes the assumption of homoscedasticity, the efficiency gains are not that important even in the case of heteroscedastic errors. This result is supported by Judson and Owen (1999), who showed empirically that the 
one-step estimator outperforms the two-step estimator, especially when the number of time periods is relatively high $(T=30)$, which is the case in this study. ${ }^{11}$

A problem that we have to deal with is the "too many instruments problem". Using too many instruments may result in over-fitting biases. When the number of time periods is relatively large, this over-fitting becomes even more serious. The consequent large collection of instruments, even if individually valid, can be collectively invalid because they over-fit endogenous variables (Doornik et al., 2002; Roodman, 2009a, b). They also weaken the Hansen test of overidentifying restrictions used to check instrument validity. Hence, to minimize the over-fitting problem we use the collapse alternative suggested by Roodman (2009b). The empirical results from this panel data analysis are presented and discussed in the next section.

\section{Main Results}

Table 2 reports the main empirical results. The specification reported in column (1) includes separate indicator variables for left- and right-wing parties. The effect of political ideology is, therefore, measured relative to centrist governments. We see that growth in genuine wealth is systematically higher under right-wing governments and

\footnotetext{
${ }^{11}$ Arellano and Bover (1995) and Blundel and Bond (1998) suggest another GMM estimator with additional moment conditions. If they are valid, they will increase the efficiency of the estimators. This is known as the system GMM estimator, which combines the moment conditions of the model in first differences with those of the model in levels. However, if the orthogonality conditions for the firstdifference equation are valid, but those for the level equation are not, then the system GMM may not be better than first-differences GMM. This can happen, for example, if the regressors used in the orthogonality conditions for the levels equation are correlated with the individual effects. Moreover, simulations suggest that the system GMM is not necessarily superior to the standard GMM in cases where the autoregressive parameter is below 0.8 and the time-series observations are relatively large (Blundell and Bond, 1998; Moshirian and Wu, 2012). This is what we observe in our data, so the estimator that seems to be more suitable for our empirical analysis is the one-step first-differences GMM estimator.
} 
that there is no difference between left-wing and centrist governments. This suggests that we can be parsimonious and merge left-wing and centrist governments into one reference group and this is done in all subsequent specifications. From the specification reported in column (2), we observe that growth in genuine wealth is higher under rightwing governments than under either left-wing or centrist governments. In column (3), we report, for comparison, a specification estimated with a fixed effects estimator rather than with the difference-GMM estimator used in the other specifications. We observe that the point estimate on Right is smaller than the GMM estimate reported in column (2), but statistically significant at the one percent level. The estimate of the persistence parameter is much large, as one would expect in the presence of Nickell bias.

The positive effect of right-wing parties on GWgrowth is not just statistically significant, it is also of economic importance. The average growth rate of genuine wealth per capita is 0.62 with a standard deviation of 1.8 (see Table 1). Accordingly, based on the estimate from column (2), a switch from a left-wing or centrist to a rightwing government increases the growth rate of genuine wealth in the average country by 0.147 percentage points or by one twelfth of a standard deviation. The long-run effect is an increase of $0.29(=0.147 /(1-0.498))$ percentage points. We interpret this as evidence that the fiscal conservatism of right-wing parties, their greater willingness to deregulate markets, and their focus on provision of merit goods pay off in terms of investments in the fundamental capital stocks and that this is sufficient to compensate for any underinvestment in natural capital.

[Insert Table 2 around here] 
In contrast to the robust evidence on the partisan cycle, the timing of elections by itself does not appear to affect the growth rate of genuine wealth. The point estimate on Election year is never statistically different from zero, rejecting the idea of an opportunistic election cycle in genuine investment. ${ }^{12}$ This is not entirely surprising. After all, it takes time to enact policies with a substantive effect on genuine investment and, on top of that, it is hard for voters to observe and attribute short-term fluctuations in these investments to government policy. An implication, then, is that it is not elections per se that create cycles in genuine investment. Rather the cycles are created by underlying ideological differences with regard to economic policy that filter through to investments in genuine wealth over the tenure of a government with a particular political ideology. In Section 5, we dwell deeper into the role played by the length of time a government has been in office.

The partisan cycles in genuine investment are a short to medium run phenomena that can cause a country to move on or off a sustainable path over time. In contrast, the nature of the underlying political institutions can have a longer-term effect on the investments that a society makes in its fundamental capital stocks. More importantly, it is likely that the nature of the partisan cycle is, at least in part, a function of the underlying institutions. If so, we run the risk of conflating the two. To investigate this issue, column (4), in Table 2, reports a specification that controls for Polity IV index. This index is a comprehensive summary measure of the quality of the political institutions in a country at a given point in time. We observe that the point estimate on

\footnotetext{
${ }^{12}$ In additional experiments, reported in Table A.1 in Annex, we investigate whether there is an election cycle in those elections which resulted in a change in the political orientation of the government, if there is an effect in pre- and post-election years, or if it matters how long the interval between elections is. Apart from the weak positive effect of elections that result in a change of the political orientation of the government, we find no robust evidence of an election cycle.
} 
Right is a little smaller than previously $(0.126)$ but remains significant. ${ }^{13}$ In contrast, the point estimate on Polity IV Index is far from statistically significant. Similar results are obtained for other broad measures of institutions. It, therefore, appears that the partisan cycle in genuine investment is separate from any effect that might come from variations in the broader institutional environment.

Yet, the many important differences in party systems that clearly exist make it, as previously noted, a challenge to measure differences in political ideology consistently across time and space. One way to engage with this is to investigate potential heterogeneity across subsamples of countries with broadly similar party systems. In Table 2, columns (5) and (6), we report specifications that split the overall sample into an OECD and a non-OECD sample. We observe that there is a strong partisan cycle in both samples, but that the point estimate on Right is larger for the sample of non-OECD countries. ${ }^{14}$ One the one hand, this suggests that the direction and qualitative nature of the association between political ideology and sustainable development is the same across societies at different levels of development and with different party systems. On the other hand, it also suggests that the amplitude of the cycle is larger outside the OECD democracies, possibly because the differences in the ideological stance of left- and right-wing governments with regard to economy policy are larger in non-OECD democracies. ${ }^{15}$

\footnotetext{
${ }^{13}$ This result is robust to the use of other summary indicators for the quality of institutions than the Polity IV index, including controls for type of political regime (Presidential versus Parliamentarian; Plurality versus non-Plurality) and for the election system (Majority versus Proportional Rule) - see Tables A.2, A.3, A.4 and A.6 in Annex.

${ }^{14}$ While in the group of OECD countries the growth rate of genuine wealth per capita is, on average, 0.13 percentage points higher when a right-wing party is in office, in the non-OECD countries it is 0.24 percentage points higher, ceteris paribus.

${ }^{15}$ Besides the split between the OECD and non-OECD countries, we also investigated alternative sample splits. Those results, reported in Tables A.2 to A.4, A.7and A.8 in Annex, show that right-wing parties
} 
With regard to the set of economic control variables, we observe from Table 2 that government consumption (Gov. consumption) have a negative impact on the growth rate of genuine wealth. GDP per capita is positively corrected with the growth rate of genuine wealth while Years of schooling is consistently insignificant and Trade openness and Urban pop. ratio are positive and significant only in the OECD subsample. Moreover, the positive relationship between right-wing parties and genuine investment is robust to changes in the proxies for the economy's capital stocks, shadow prices and time periods. ${ }^{16}$

\section{Additional results: Tenure in office}

In the same way as it takes time for the captain of a super tanker to change the ship's course, it takes time for a government to change the package of economic policies and for these policies to filter through to investments in genuine wealth. A long period in power is generally necessary to allow a government to fully implement its medium-term policies. The more time a government spends in office, the more scope it has to ensure consistency across different dimensions of its economic and social policies. Frequent changes in government, on the other hand, tend to see such efforts interrupted or reverted. It is, therefore, reasonable, on the one hand, to expect that the number of years that a government rules could have an independent effect on genuine investment and, on the other, that it may interact with the partisan cycle we identified above.

affects investment in genuine wealth in presidential, plurality and proportional representation regimes and are observed in both high or low income countries/democracies.

${ }^{16}$ See Tables A.5 and A.9 in Annex. 
In all the specifications reported in Table 2, we include the variable Party tenure to investigate if years in office have an independent effect on GWgrowth. The answer is clearly no. The point estimate on this variable is insignificant, with the one exception that there is a marginally significant positive effect in the OECD sample (column (5)). It is, of course, possible that the impact of time in office is non-linear, reflecting the natural life cycle of governments. On the one hand, as already noted, more years in office enables a party to implement its policy agenda. On the other hand, the literature on vote and popularity functions documents that a government's popularity erodes with time in office. ${ }^{17}$ As this "cost of ruling" reduces a government's general popularity, it may switch to more populist policies. We may, therefore, observe a switch from medium-term policies that have a positive effect on genuine investment to short-term policies that have a negative effect as a government "ages" in office. ${ }^{18}$ This suggests that the relationship between time in office and investment in genuine wealth follows an inverted U-shaped relationship. Table 3, column (1), reports a specification with Party tenure and its square. We see that both coefficients are insignificant and that the point estimate on the indicator variable Right is unaffected by this. Taken together, this rejects the hypothesis that years in office exerts an independent (linear or non-linear) effect on genuine investment.

This, however, does not rule out that time in office could interact with the partisan cycle in genuine investment. To test for this, we interact the indicator variable for right-wing parties, Right, with Party tenure and its square. Table 3, column (2), reports the results. We observe that the relationship between the years that a right-wing

\footnotetext{
${ }^{17}$ See, for example, the seminal paper by Mueller (1970) and Veiga and Veiga (2004).

18 This effect may be reinforced by the fact that there tend to be more natural or forced cabinet changes towards the end of the life-span of a government. This, in turn, may reduce the efficacy of medium-term policies since the strategies for implementing those policies normally depend on the leader's vision.
} 
party holds office and investment in genuine wealth follows an inverted U-shaped relationship. ${ }^{19}$ The estimated maximum is reached after 15 years in office. The average number of years in office is 7.5 years with a standard deviation of 9.45. Accordingly, most of our sample is located on the upwards sloping part of the relationship, but there are some observations also on the downwards sloping part. This suggests that while the policies enacted by right-wing parties are "good news" for sustainable development in general, the positive effect wears off with years in office and may, in some extreme cases, become negative. Columns (3) and (4) in Table 3 report results for the OECD and non-OECD subsamples, respectively. The non-linear effect is present in both. ${ }^{20}$ In Table 3, columns (5) to (8), we investigate the effect of the years that the party leader (rather than the party itself) has been in power. Again, we find no direct effect (columns (5) and (6)), but the effect of right-wing parties on genuine investment does interact with the number of years that the party leader (Leader tenure) has been in power. The interaction is not, however, non-linear: only the interaction between Right and Leader tenure is statistically significant (column (8)).

\section{[Insert Table 3 around here]}

\section{Conclusions}

The question of sustainable development has become increasingly important for many observers and policymakers. Climate change, aging populations, debt crisis popping out in many countries and other important social and economic challenges have

\footnotetext{
${ }^{19}$ The interaction Right*Party tenure is not statistically significant in specifications without the quadratic term.

${ }^{20}$ The maximum for the OECD sample is reached at 13 years in office, while for non-OECD countries it is estimated to be 24 years.
} 
highlighted the importance of studying the subject. Sustainability is naturally linked to issues of governance in general and to policy decisions made by the governments in particular. These policy decisions depend on political ideology and electoral concerns.

In this paper, we add to the substantial existing literature on the influence of political ideology and electoral politics on public policy by studying the effect of ideology on investment in genuine wealth. We find strong evidence that the government's ideological colour matters and that investment in genuine wealth is higher when right-wing governments are in office. Economic conservatism attributed to rightwing parties and their greater willingness to deregulate the economy may be driving this effect. These results are robust and hold across all alternative specifications and subsamples tested. In contrast, our results clearly rule out the existence of opportunistic election cycles. The expansion/contraction cycle near elections (if it actually occurs) does not seem to affect genuine investment.

Furthermore, the time a right wing government remains in office also appears to positively impact sustainable development, although it seems that this positive effect decays over time. Increasing costs of ruling and overall efficiency reduction faced by governments may help explain this result.

\section{Acknowledgments}

Vitor Castro wishes to thank the financial support provided by the Portuguese Foundation for Science and Technology under the research grant SFRH/BSAB/113588/2015 (partially funded by COMPTE, QREN and FEDER). 


\section{References}

Aidt, T., 2011. Corruption and sustainable development. In: Rose-Ackerman, S., Soreide, T. (Eds.). International Handbook on the Economics of Corruption, Vol. II, Ch. 1. Cheltenham, UK: Edward Elgar Publishing.

Aidt, T., Veiga, F., 2016. Institutions and sustainable development. Unpublished working paper.

Alesina. A., 1987. Macroeconomic Policy in a Two-Party System as a Repeated Game. Quarterly Journal of Economics, 102, 651-678.

Arellano, M., Bond, S., 1991. Some Tests of Specification for Panel Data: Monte Carlo Evidence and an Application to Employment Equations. Review of Economic Studies, 58, 277-297.

Arellano, M., Bover, S., 1995. Another look at the instrumental variable estimation of error components models. Journal of Econometrics, 68, 29-51.

Arrow, K., Dasgupta, P., Mäler, K., 2003. The Genuine Savings Criterion and the Value of Population. Economic Theory, 21(2), 217-225.

Arrow, K., Dasgupta, P., Goulder, L., Daily, G., Ehrlich, P., Heal, G., Levin, S., Mäler, K., Schneider, S., Starrett, D., Walker, B., 2004. Are We Consuming Too Much? The Journal of Economic Perspectives, 18(3), 147-172.

Baltagi, B., 2008. Econometric Analysis of Panel Data, 4th Ed. Chichester, UK. John Wiley \& Sons, Ltd.

Bjørnskov, C., 2005. Does political ideology affect economic growth? Public Choice, 123(2), 133-146.

Bjørnskov, C., 2008. The growth-inequality association: government ideology matters. Journal of Development Economics, 87(2), 300-308.

Bjørnskov, C., Potrafke, N., 2012. Political ideology and economic freedom across Canadian provinces. Eastern Economic Journal, 38, 143-166.

Bjørnskov, C. Potrafke, N., 2013. The size and scope of government in the US states: does party ideology matter? International Tax and Public Finance 20, 987-714.

Blundell R., Bond, S., 1998. Initial conditions and moment restrictions in dynamic panel data models. Journal of Econometrics, 87(1), 115-143.

Bruno, G., 2005a. Estimation and inference in dynamic unbalanced panel-data models with a small number of individuals. Stata Journal, 5(4), 473-500. 
Bruno, G., 2005b. Approximating the bias of the LSDV estimator for dynamic unbalanced panel data models. Economics Letters, 87(3), 361-366.

Dasgupta, P., 2010. The Place of Nature in Economic Development, in Dani Rodrik and Mark Rosenzweig, eds., 2010. Handbook of Development Economics, Vol. 5 (Amsterdam: North Holland). 4977-5047.

Dasgupta, P., Mäler, K., 2000. Net National Product, Wealth, and Social Well-being. Environment and Development Economics, 5(1) 69-93.

Dasgupta, P., 2001. Human Well-being and the Natural Environment (Oxford: Oxford University Press).

Doornik, J., Arellano, M., Bond, S., 2002. Panel Data Estimation Using DPD for OX: Manuscript. Oxford University.

Dubois, E., 2016. Political business cycles 40 years after Nordhaus. Public Choice, In Press.

Fleurbaey, M., 2009. Beyond GDP: The Quest for a Measure of Social Welfare. Journal of Economic Literature 474, 1029-1075.

Frederiksson, P. G.,Wang, L., Warren, P. L., 2013. Party politics, governors and economic policy. Southern Economic Journal, 80(1), 106-126.

Hibbs, D. A., 1977, Political Parties and Macroeconomic Policy. American Political Science Review, 71, 1467-1487.

Hibbs, D. A., 1987, The American Political Economy: Macroeconomics and Electoral Politics in the United States (Harvard University Press, Cambridge, MA).

Hibbs, D. A., 1992, Partisan Theory After Fifteen Years. European Journal of Political Economy, 8, 361-373.

Hibbs, D., 2006. Voting and the Macroeconomy. In B. R. Weingast \& D. A. Wittman Eds., The Oxford handbook of political economy pp. 565-586. Oxford: Oxford University Press.

Hibbs, D., 2006. Voting and the Macroeconomy. In B. R. Weingast \& D. A. Wittman Eds., The Oxford handbook of political economy pp. 565-586. Oxford: Oxford University Press.

Imbeau, L., Pétry, F., Lamari, M., 2001. Left-right party ideology and government policies: a meta-analysis. European Journal of Political Research, 40(1), 1-29.

Kauder, B., Potrafke, N. 2013. Government Ideology and Tuition Fee Policy: Evidence from the German States. CESifo Economic Studies, 59 (4), 628-649. 
Moshirian, F., Wu, Q., 2012. Banking industry volatility and economic growth. Research in International Business and Finance, 26, 428-442.

Mueller, J.E., 1970. Presidential popularity from Truman to Johnson. American Political Science Review, 64, 18-23.

Nordhaus, W. D., 1975. The Political Business Cycle. Review of Economic Studies, XLII2, 169-190.

Pickering, A., Rockey, J., 2011. Ideology and the growth of government. Review of Economics and Statistics, 93(3), 907-919.

Potrafke, N., 2010. Does government ideology influence deregulation of product markets? Empirical evidence from OECD countries. Public Choice, 143(1-2), $135-155$.

Reed, W. R., 2006. Democrats, republicans, and taxes: evidence that political parties matter. Journal of Public Economics, 90(4-5), 725-750.

Rogoff, K., 1990. Equilibrium Political Budget Cycles. The American Economic Review, 801, 21-36.

Rogoff, K., Sibert, A., 1988. Elections and Macroeconomic Policy Cycles. Review of Economic Studies, LV1, 1-16.

Roodman, D. M. 2009b. A note on the theme of too many instruments. Oxford Bulletin of Economics and Statistics 71: 135-158.

Roodman, D., 2009a. How to do xtabond2: An introduction to difference and system GMM in Stata. Stata Journal, 9(1), 86-136.

Veiga, F., Veiga, L. (2004). The determinants of vote intentions in Portugal. Public Choice, 118(3-4), 341-364. 
Table 1. Description of the variables and descriptive statistics

\begin{tabular}{|c|c|c|c|c|c|c|}
\hline Variable & Description & Obs. & Mean & S.D. & Min. & Max \\
\hline GWgrowth & $\begin{array}{l}\text { Growth in genuine wealth per capita; } \\
\text { equal to adjusted net savings (excluding } \\
\text { particulate emissions) multiplied by the } \\
\text { GNI-wealth ratio ( } 0.15 \text { for developing and } \\
0.2 \text { for industrialized countries) and } \\
\text { subtracted by the average population } \\
\text { growth rate. }\end{array}$ & 1817 & 0.62 & 1.80 & -7.77 & 4.66 \\
\hline Left & $\begin{array}{l}\text { Dummy variable that takes de value of } 1 \\
\text { when a left-wing party is in office; and } 0 \text {, } \\
\text { otherwise (center or right-wing party). }\end{array}$ & 2042 & 0.41 & 0.49 & 0 & 1 \\
\hline Right & $\begin{array}{l}\text { Dummy variable that takes de value of } 1 \\
\text { when a right-wing party is in office; and } 0 \text {, } \\
\text { otherwise (centre or left-wing party). }\end{array}$ & 2042 & 0.45 & 0.50 & 0 & 1 \\
\hline Party tenure & The number of years a party is in office. & 2029 & 7.54 & 9.45 & 1 & 71 \\
\hline Leader tenure & $\begin{array}{l}\text { The number of years a chief executive is } \\
\text { in office. }\end{array}$ & 2037 & 4.10 & 3.66 & 1 & 31 \\
\hline Election year & $\begin{array}{l}\text { Dummy variable that takes de value of } 1 \\
\text { in the year of legislative elections; and } 0 \text {, } \\
\text { otherwise. }\end{array}$ & 2042 & 0.27 & 0.44 & 0 & 1 \\
\hline Gov. consumption & $\begin{array}{l}\text { General government final consumption } \\
\text { expenditure }(\% \text { of GDP). }\end{array}$ & 1999 & 16.60 & 5.62 & 2.80 & 54.52 \\
\hline Years of schooling & Average years of schooling. & 1864 & 8.14 & 2.87 & 0.70 & 13.10 \\
\hline GDP per capita & Real GDP per capita (thousands of USD). & 2012 & 15.79 & 15.89 & 0.19 & 86.13 \\
\hline Trade openness & $\begin{array}{l}\text { Trade (Imports plus Exports as } \% \text { of } \\
\text { GDP). }\end{array}$ & 2027 & 71.88 & 39.95 & 9.10 & 352.90 \\
\hline Urban pop. ratio & $\begin{array}{l}\text { Urban population over total population } \\
(\%) \text {. }\end{array}$ & 2042 & 63.81 & 21.48 & 7.83 & 97.73 \\
\hline Polity IV index & $\begin{array}{l}\text { Autocracy-Democracy index; it describes } \\
\text { how democratic a country is in a polity } \\
\text { scale ranging from }-10 \text { (strongly } \\
\text { autocratic) to }+10 \text { (strongly democratic). }\end{array}$ & 1350 & 8.62 & 2.28 & -8 & 10 \\
\hline
\end{tabular}

Sources: World Development Indicators (1970-2013) of the World Bank (http://data.worldbank.org/) for the dependent variable (see Arrow et al, 2003 and Aidt, 2011) and for the economic and demographic covariates. Database of Political Institutions (1970-2012), World Bank (http://www.worldbank.org) for the political variables. The institutional variable (Polity IV index) comes from the Polity IV database.

Notes: The countries used in the estimations are the following: Albania, Algeria, Argentina, Australia, Austria, Belgium, Bolivia, Botswana, Brazil, Bulgaria, Canada, Chile, Colombia, Costa Rica, Croatia, Cyprus, Czech Republic, Denmark, Dominican Republic, Ecuador, El Salvador, Estonia, Finland, France, Gambia, Germany, Ghana, Greece, Guatemala, Honduras, Hungary, Iceland, India, Ireland, Israel, Italy, Jamaica, Japan, Rep. Korea, Latvia, Luxembourg, Macedonia, Madagascar, Malawi, Mali, Mexico, Moldova, Mozambique, Nepal, Netherlands, New Zealand, Nicaragua, Niger, Nigeria, Norway, Pakistan, Papua New Guinea, Paraguay, Peru, Philippines, Poland, Portugal, Romania, Russian Federation, Senegal, Sierra Leone, Slovak Republic, Slovenia, South Africa, Spain, Sri Lanka, Sweden, Switzerland, Thailand, Trinidad and Tobago, Turkey, Uganda, Ukraine, United Kingdom, United States, Uruguay, and Venezuela. 
Table 2. The effects of the political ideology on sustainable development

\begin{tabular}{|c|c|c|c|c|c|c|}
\hline & $(1)$ & $(2)$ & (3) & (4) & $(5)$ & (6) \\
\hline GWgrowth $_{t-1}$ & $\begin{array}{c}0.497 * * * \\
(0.174)\end{array}$ & $\begin{array}{c}0.498 * * * \\
(0.174)\end{array}$ & $\begin{array}{c}0.665^{* * *} * \\
(0.061)\end{array}$ & $\begin{array}{c}0.753 * * * \\
(0.123)\end{array}$ & $\begin{array}{c}0.555^{* * * *} \\
(0.103)\end{array}$ & $\begin{array}{c}0.305^{* *} \\
(0.120)\end{array}$ \\
\hline Left & $\begin{array}{c}0.113 \\
(0.083)\end{array}$ & & & & & \\
\hline Right & $\begin{array}{c}0.234 * * * \\
(0.070)\end{array}$ & $\begin{array}{c}0.147 * * * \\
(0.049)\end{array}$ & $\begin{array}{c}0.092 * * * \\
(0.033)\end{array}$ & $\begin{array}{c}0.126^{* *} \\
(0.049)\end{array}$ & $\begin{array}{c}0.133 * * * \\
(0.049)\end{array}$ & $\begin{array}{c}0.241 * * * \\
(0.093)\end{array}$ \\
\hline Party tenure & $\begin{array}{l}-0.001 \\
(0.006)\end{array}$ & $\begin{array}{l}-0.001 \\
(0.006)\end{array}$ & $\begin{array}{l}-0.001 \\
(0.002)\end{array}$ & $\begin{array}{c}0.006 \\
(0.004)\end{array}$ & $\begin{array}{l}0.007^{*} \\
(0.004)\end{array}$ & $\begin{array}{l}-0.009 \\
(0.010)\end{array}$ \\
\hline Election year & $\begin{array}{c}0.032 \\
(0.033)\end{array}$ & $\begin{array}{c}0.032 \\
(0.033)\end{array}$ & $\begin{array}{c}0.014 \\
(0.034)\end{array}$ & $\begin{array}{c}0.011 \\
(0.037)\end{array}$ & $\begin{array}{c}0.050 \\
(0.035)\end{array}$ & $\begin{array}{c}0.027 \\
(0.060)\end{array}$ \\
\hline Gov. consumption & $\begin{array}{c}-0.048 * * \\
(0.022)\end{array}$ & $\begin{array}{c}-0.048 * * \\
(0.022)\end{array}$ & $\begin{array}{c}-0.027 * * * \\
(0.008)\end{array}$ & $\begin{array}{c}-0.070 * * * \\
(0.021)\end{array}$ & $\begin{array}{c}-0.142 * * * \\
(0.022)\end{array}$ & $\begin{array}{c}-0.034^{* *} \\
(0.016)\end{array}$ \\
\hline Years of schooling & $\begin{array}{c}-0.030 \\
(0.138)\end{array}$ & $\begin{array}{l}-0.034 \\
(0.138)\end{array}$ & $\begin{array}{l}-0.051 \\
(0.053)\end{array}$ & $\begin{array}{l}-0.023 \\
(0.142)\end{array}$ & $\begin{array}{c}0.117 \\
(0.127)\end{array}$ & $\begin{array}{l}-0.414 \\
(0.287)\end{array}$ \\
\hline $\operatorname{Ln}(G D P$ per capita $)$ & $\begin{array}{c}1.869 * * * \\
(0.631)\end{array}$ & $\begin{array}{c}1.853 * * * \\
(0.633)\end{array}$ & $\begin{array}{c}0.692 \text { ** } \\
(0.272)\end{array}$ & $\begin{array}{c}1.642^{* * *} * \\
(0.623)\end{array}$ & $\begin{array}{c}0.924 \\
(0.722)\end{array}$ & $\begin{array}{c}2.227 * * \\
(0.946)\end{array}$ \\
\hline Trade openness & $\begin{array}{l}-0.007 \\
(0.007)\end{array}$ & $\begin{array}{l}-0.007 \\
(0.007)\end{array}$ & $\begin{array}{c}0.001 \\
(0.002)\end{array}$ & $\begin{array}{l}-0.011 \\
(0.009)\end{array}$ & $\begin{array}{c}0.014 * * \\
(0.005)\end{array}$ & $\begin{array}{c}-0.016^{* *} \\
(0.008)\end{array}$ \\
\hline Urban pop. ratio & $\begin{array}{c}0.037 \\
(0.030)\end{array}$ & $\begin{array}{c}0.036 \\
(0.030)\end{array}$ & $\begin{array}{c}0.011 \\
(0.012)\end{array}$ & $\begin{array}{c}0.025 \\
(0.033)\end{array}$ & $\begin{array}{c}0.057 * * \\
(0.028)\end{array}$ & $\begin{array}{c}0.032 \\
(0.047)\end{array}$ \\
\hline Polity IV index & & & & $\begin{array}{c}0.040 \\
(0.067)\end{array}$ & & \\
\hline \# Observations & 1533 & 1533 & 1637 & 1164 & 789 & 744 \\
\hline \# Countries & 78 & 78 & 79 & 56 & 31 & 47 \\
\hline \# Instruments & 82 & 81 & & 82 & 81 & 81 \\
\hline Sample & Full & Full & Full & Full & OECD & Non-OECD \\
\hline Hansen $J$-test & 0.329 & 0.311 & & 0.967 & 1.000 & 1.000 \\
\hline $\operatorname{AR}(1)$ & 0.000 & 0.000 & & 0.000 & 0.003 & 0.000 \\
\hline $\operatorname{AR}(2)$ & 0.264 & 0.267 & & 0.332 & 0.237 & 0.150 \\
\hline $\mathrm{R}^{2}$ & & & 0.526 & & & \\
\hline
\end{tabular}

Notes: See Table 1 for definitions. The dependent variable is GWgrowth. Robust standard errors are in parentheses; significance levels at which the null hypothesis is rejected: ***, 1\%;**, 5\%, and *, 10\%. Year fixed-effects are controlled for in all estimations. A difference-GMM estimator is employed, except in regression (3) where a FE estimator is used instead; the lag of the dependent variable is treated as endogenous in the GMM estimations (only one-step estimates are reported here, but the results remain unchanged with a two-step estimator - those are not reported here but they are available upon request); the respective lagged values and the other explanatory variables are used as instruments in the first-difference equation; they were collapsed to avoid the problem of having too many instruments. The Hansen $J$-test reports the $p$-value for the null hypothesis of instrument validity. The values reported for $\operatorname{AR}(1)$ and $\operatorname{AR}(2)$ are the $p$-values for first and second order auto-correlated disturbances in the first differences equations. Separate estimations for OECD and non-OECD countries are reported in columns (5) and (6), respectively. Three OECD countries are dropped in the estimations: Estonia (due to few observations and lack of variability), Iceland (very few observations for the dependent variable) and Switzerland (no variability in the ideology; always right-wing governments). 
Table 3. Ideology and time in office interactions

\begin{tabular}{|c|c|c|c|c|c|c|c|c|}
\hline & (1) & $(2)$ & (3) & (4) & (5) & $(6)$ & (7) & $(8)$ \\
\hline GWgrowth $_{t-1}$ & $\begin{array}{c}0.496 * * * \\
(0.174)\end{array}$ & $\begin{array}{c}0.491 * * * \\
(0.173)\end{array}$ & $\begin{array}{c}0.556^{* * * *} \\
(0.100)\end{array}$ & $\begin{array}{c}0.300^{* *} \\
(0.129)\end{array}$ & $\begin{array}{c}0.500 * * * \\
(0.173)\end{array}$ & $\begin{array}{c}0.500 * * * \\
(0.175)\end{array}$ & $\begin{array}{c}0.497 * * * \\
(0.174)\end{array}$ & $\begin{array}{c}0.499 * * * * \\
(0.173)\end{array}$ \\
\hline Right & $\begin{array}{c}0.143 * * * \\
(0.048)\end{array}$ & & & & $\begin{array}{c}0.151^{* * * *} \\
(0.049)\end{array}$ & $\begin{array}{c}0.150 * * * \\
(0.049)\end{array}$ & & \\
\hline Party tenure & $\begin{array}{c}0.009 \\
(0.010)\end{array}$ & & & & & & & \\
\hline$(\text { Party tenure })^{\wedge} 2$ & $\begin{array}{l}-0.000 \\
(0.000)\end{array}$ & & & & & & & \\
\hline Right*Party tenure & & $\begin{array}{c}0.030 * * * \\
(0.012)\end{array}$ & $\begin{array}{c}0.026 * * \\
(0.011)\end{array}$ & $\begin{array}{c}0.048 * * \\
(0.023)\end{array}$ & & & & \\
\hline$\left(\text { Right }{ }^{*} \text { Party tenure }\right)^{\wedge} 2$ & & $\begin{array}{c}-0.001 * * * \\
(0.000)\end{array}$ & $\begin{array}{c}-0.001 * * \\
(0.000)\end{array}$ & $\begin{array}{c}-0.001 * * \\
(0.000)\end{array}$ & & & & \\
\hline Leader tenure & & & & & $\begin{array}{c}0.007 \\
(0.009)\end{array}$ & $\begin{array}{l}-0.005 \\
(0.019)\end{array}$ & & \\
\hline$(\text { Leader tenure })^{\wedge} 2$ & & & & & & $\begin{array}{c}0.001 \\
(0.001)\end{array}$ & & \\
\hline Right*Leader tenure & & & & & & & $\begin{array}{c}0.026 \\
(0.018)\end{array}$ & $\begin{array}{c}0.024 * * \\
(0.010)\end{array}$ \\
\hline$(\text { Right } * \text { Leader tenure })^{\wedge} 2$ & & & & & & & $\begin{array}{c}-0.000 \\
(0.001)\end{array}$ & \\
\hline Election year & $\begin{array}{c}0.026 \\
(0.034)\end{array}$ & $\begin{array}{c}0.021 \\
(0.032)\end{array}$ & $\begin{array}{c}0.049 \\
(0.035)\end{array}$ & $\begin{array}{c}0.003 \\
(0.056)\end{array}$ & $\begin{array}{c}0.024 \\
(0.032)\end{array}$ & $\begin{array}{c}0.027 \\
(0.032)\end{array}$ & $\begin{array}{c}0.020 \\
(0.031)\end{array}$ & $\begin{array}{c}0.020 \\
(0.031)\end{array}$ \\
\hline Gov. consumption & $\begin{array}{c}-0.048 * * \\
(0.022)\end{array}$ & $\begin{array}{c}-0.048^{* *} \\
(0.022)\end{array}$ & $\begin{array}{c}-0.139 * * * \\
(0.023)\end{array}$ & $\begin{array}{c}-0.035^{* *} \\
(0.016)\end{array}$ & $\begin{array}{c}-0.048 * * \\
(0.022)\end{array}$ & $\begin{array}{c}-0.048 * * \\
(0.022)\end{array}$ & $\begin{array}{c}-0.048 * * \\
(0.022)\end{array}$ & $\begin{array}{c}-0.048^{* *} \\
(0.021)\end{array}$ \\
\hline Years of schooling & $\begin{array}{c}-0.032 \\
(0.138)\end{array}$ & $\begin{array}{c}-0.021 \\
(0.137)\end{array}$ & $\begin{array}{c}0.141 \\
(0.125)\end{array}$ & $\begin{array}{l}-0.422 \\
(0.288)\end{array}$ & $\begin{array}{l}-0.036 \\
(0.141)\end{array}$ & $\begin{array}{c}-0.036 \\
(0.140)\end{array}$ & $\begin{array}{l}-0.029 \\
(0.142)\end{array}$ & $\begin{array}{l}-0.031 \\
(0.143)\end{array}$ \\
\hline $\operatorname{Ln}(G D P$ per capita $)$ & $\begin{array}{c}1.836 * * * \\
(0.629)\end{array}$ & $\begin{array}{c}1.854 * * * \\
(0.637)\end{array}$ & $\begin{array}{c}0.998 * * \\
(0.509)\end{array}$ & $\begin{array}{c}2.196 * * \\
(0.966)\end{array}$ & $\begin{array}{c}1.822 * * * \\
(0.633)\end{array}$ & $\begin{array}{c}1.860 * * * \\
(0.638)\end{array}$ & $\begin{array}{c}1.824 * * * \\
(0.633)\end{array}$ & $\begin{array}{c}1.806 * * * \\
(0.629)\end{array}$ \\
\hline Trade openness & $\begin{array}{l}-0.007 \\
(0.007)\end{array}$ & $\begin{array}{l}-0.007 \\
(0.007)\end{array}$ & $\begin{array}{c}0.014 * * \\
(0.006)\end{array}$ & $\begin{array}{c}-0.016^{* *} \\
(0.008)\end{array}$ & $\begin{array}{l}-0.007 \\
(0.007)\end{array}$ & $\begin{array}{l}-0.007 \\
(0.007)\end{array}$ & $\begin{array}{l}-0.007 \\
(0.007)\end{array}$ & $\begin{array}{c}-0.007 \\
(0.007)\end{array}$ \\
\hline Urban pop. ratio & $\begin{array}{c}0.035 \\
(0.030)\end{array}$ & $\begin{array}{c}0.034 \\
(0.031)\end{array}$ & $\begin{array}{c}0.058 * * \\
(0.027)\end{array}$ & $\begin{array}{c}0.030 \\
(0.047)\end{array}$ & $\begin{array}{c}0.032 \\
(0.030)\end{array}$ & $\begin{array}{c}0.030 \\
(0.032)\end{array}$ & $\begin{array}{c}0.032 \\
(0.031)\end{array}$ & $\begin{array}{c}0.032 \\
(0.031)\end{array}$ \\
\hline \# Observations & 1533 & 1533 & 789 & 744 & 1534 & 1534 & 1534 & 1534 \\
\hline \# Countries & 78 & 78 & 31 & 47 & 78 & 78 & 78 & 78 \\
\hline \# Instruments & 82 & 81 & 81 & 81 & 81 & 82 & 81 & 80 \\
\hline Sample & Full & Full & OECD & Non-OECD & Full & Full & Full & Full \\
\hline Hansen $J$-test & 0.351 & 0.337 & 1.000 & 1.000 & 0.243 & 0.292 & 0.281 & 0.147 \\
\hline $\mathrm{AR}(1)$ & 0.000 & 0.000 & 0.002 & 0.000 & 0.000 & 0.000 & 0.000 & 0.000 \\
\hline $\operatorname{AR}(2)$ & 0.272 & 0.268 & 0.245 & 0.138 & 0.264 & 0.260 & 0.254 & 0.255 \\
\hline
\end{tabular}

Notes: See Tables 1 and 2. The dependent variable is GWgrowth. Robust standard errors are in parentheses; significance levels at which the null hypothesis is rejected: ***, $1 \%$; **, 5\%, and *, 10\%. Year fixed-effects are controlled for in all estimations. A difference-GMM estimator is employed, where the lag of the dependent variable is treated as endogenous in the GMM estimations; the respective lagged values and the other explanatory variables are used as instruments in the first-difference equation; they were collapsed to avoid the problem of having too many instruments. Separate estimations for OECD and nonOECD countries are reported in columns (3) and (4), respectively. 
ANNEX

Table A1. Elections cycle and sustainable development

\begin{tabular}{|c|c|c|c|c|c|c|c|c|c|c|}
\hline & $(1)$ & $(2)$ & (3) & (4) & $(5)$ & $(6)$ & $(7)$ & $(8)$ & (9) & $(10)$ \\
\hline GWgrowth t-I & $\begin{array}{c}0.5022 * * * \\
(0.1735)\end{array}$ & $\begin{array}{c}0.5149 * * * \\
(0.1887)\end{array}$ & $\begin{array}{c}0.4510 * * * \\
(0.1726)\end{array}$ & $\begin{array}{c}0.5150 * * * \\
(0.1989)\end{array}$ & $\begin{array}{c}0.5184 * * * \\
(0.1979)\end{array}$ & $\begin{array}{c}0.4943 * * * \\
(0.1728)\end{array}$ & $\begin{array}{c}0.5088 * * * \\
(0.1876)\end{array}$ & $\begin{array}{c}0.4476 * * * \\
(0.1713)\end{array}$ & $\begin{array}{c}0.5097 * * \\
(0.1983)\end{array}$ & $\begin{array}{c}0.5172 * * * \\
(0.1977)\end{array}$ \\
\hline Right & $\begin{array}{c}0.1453 * * * \\
(0.0488)\end{array}$ & $\begin{array}{c}0.1407 * * * \\
(0.0507)\end{array}$ & $\begin{array}{c}0.1156^{* *} \\
(0.0491)\end{array}$ & $\begin{array}{c}0.1447 * * * \\
(0.0510)\end{array}$ & $\begin{array}{c}0.1482 * * * \\
(0.0510)\end{array}$ & & & & & \\
\hline Party tenure & $\begin{array}{l}-0.0027 \\
(0.0060)\end{array}$ & $\begin{array}{l}-0.0001 \\
(0.0064)\end{array}$ & $\begin{array}{l}0.0067 * \\
(0.0038)\end{array}$ & $\begin{array}{c}0.0016 \\
(0.0076)\end{array}$ & & & & & & \\
\hline Right $*$ Party tenure & & & & & & $\begin{array}{c}0.0281 * * * \\
(0.0107)\end{array}$ & $\begin{array}{c}0.0296 * * \\
(0.0119)\end{array}$ & $\begin{array}{r}0.0292 * * \\
(0.0122)\end{array}$ & $\begin{array}{c}0.0305 * * * \\
(0.0115)\end{array}$ & \\
\hline$(\text { Right } * \text { Party tenure })^{\wedge} 2$ & & & & & & $\begin{array}{c}-0.0007 * * * \\
(0.0002)\end{array}$ & $\begin{array}{c}-0.0007 * * * \\
(0.0003)\end{array}$ & $\begin{array}{c}-0.0006 * * \\
(0.0003)\end{array}$ & $\begin{array}{c}-0.0006 * * \\
(0.0003)\end{array}$ & \\
\hline Leader tenure & & & & & $\begin{array}{c}0.0062 \\
(0.0092)\end{array}$ & & & & & \\
\hline Right*Leader tenure & & & & & & & & & & $\begin{array}{c}0.0253 * * \\
(0.0103)\end{array}$ \\
\hline Election Gov change & $\begin{array}{l}0.1026 * \\
(0.0544)\end{array}$ & & & & & $\begin{array}{c}0.0745 \\
(0.0544)\end{array}$ & & & & \\
\hline Before Election & & $\begin{array}{l}-0.0254 \\
(0.0346)\end{array}$ & & & & & $\begin{array}{l}-0.0310 \\
(0.0340)\end{array}$ & & & \\
\hline Election year & & $\begin{array}{c}0.0155 \\
(0.0370)\end{array}$ & & & & & $\begin{array}{c}0.0024 \\
(0.0354)\end{array}$ & & & \\
\hline After Election & & & $\begin{array}{c}0.0174 \\
(0.0282)\end{array}$ & & & & & $\begin{array}{c}0.0197 \\
(0.0282)\end{array}$ & & \\
\hline Election timing & & & & $\begin{array}{c}0.0092 \\
(0.0545)\end{array}$ & $\begin{array}{l}-0.0011 \\
(0.0519)\end{array}$ & & & & $\begin{array}{l}-0.0104 \\
(0.0509)\end{array}$ & $\begin{array}{l}-0.0127 \\
(0.0504)\end{array}$ \\
\hline Gov consumption & $\begin{array}{c}-0.0494 * * \\
(0.0221)\end{array}$ & $\begin{array}{c}-0.0483 * * \\
(0.0229)\end{array}$ & $\begin{array}{c}-0.0421 * * \\
(0.0195)\end{array}$ & $\begin{array}{c}-0.0462 * * \\
(0.0210)\end{array}$ & $\begin{array}{c}-0.0460 * * \\
(0.0208)\end{array}$ & $\begin{array}{c}-0.0492 * * \\
(0.0221)\end{array}$ & $\begin{array}{c}-0.0482 * * \\
(0.0228)\end{array}$ & $\begin{array}{c}-0.0419 * * \\
(0.0193)\end{array}$ & $\begin{array}{c}-0.0460 * * \\
(0.0208)\end{array}$ & $\begin{array}{c}-0.0451 * * \\
(0.0204)\end{array}$ \\
\hline Years Schooling & $\begin{array}{l}-0.0310 \\
(0.1394)\end{array}$ & $\begin{array}{c}0.0200 \\
(0.1359)\end{array}$ & $\begin{array}{l}-0.0267 \\
(0.1379)\end{array}$ & $\begin{array}{l}-0.0377 \\
(0.1452)\end{array}$ & $\begin{array}{l}-0.0460 \\
(0.1479)\end{array}$ & $\begin{array}{l}-0.0188 \\
(0.1384)\end{array}$ & $\begin{array}{c}0.0297 \\
(0.1360)\end{array}$ & $\begin{array}{l}-0.0232 \\
(0.1377)\end{array}$ & $\begin{array}{l}-0.0229 \\
(0.1456)\end{array}$ & $\begin{array}{l}-0.0440 \\
(0.1509)\end{array}$ \\
\hline LnGDP per capita & $\begin{array}{c}1.9141 * * * \\
(0.6455)\end{array}$ & $\begin{array}{c}1.9921 * * * \\
(0.7023)\end{array}$ & $\begin{array}{c}1.9669 * * * \\
(0.6133)\end{array}$ & $\begin{array}{c}1.9914 * * * \\
(0.6814)\end{array}$ & $\begin{array}{c}1.9764 * * * \\
(0.6828)\end{array}$ & $\begin{array}{c}1.8907 * * * \\
(0.6418)\end{array}$ & $\begin{array}{c}2.0109 * * * \\
(0.7118)\end{array}$ & $\begin{array}{c}2.0000 * * * \\
(0.6244)\end{array}$ & $\begin{array}{c}2.0120 * * * \\
(0.6908)\end{array}$ & $\begin{array}{c}1.9706 * * * \\
(0.6838)\end{array}$ \\
\hline Trade openness & $\begin{array}{l}-0.0074 \\
(0.0068)\end{array}$ & $\begin{array}{l}-0.0068 \\
(0.0071)\end{array}$ & $\begin{array}{l}-0.0064 \\
(0.0070)\end{array}$ & $\begin{array}{c}-0.0093 \\
(0.0067)\end{array}$ & $\begin{array}{c}-0.0092 \\
(0.0067)\end{array}$ & $\begin{array}{c}-0.0072 \\
(0.0068)\end{array}$ & $\begin{array}{l}-0.0066 \\
(0.0071)\end{array}$ & $\begin{array}{l}-0.0062 \\
(0.0070)\end{array}$ & $\begin{array}{l}-0.0090 \\
(0.0067)\end{array}$ & $\begin{array}{c}-0.0091 \\
(0.0067)\end{array}$ \\
\hline Urban pop ratio & $\begin{array}{c}0.0370 \\
(0.0308)\end{array}$ & $\begin{array}{c}0.0296 \\
(0.0342)\end{array}$ & $\begin{array}{c}0.0213 \\
(0.0300)\end{array}$ & $\begin{array}{c}0.0331 \\
(0.0319)\end{array}$ & $\begin{array}{c}0.0296 \\
(0.0312)\end{array}$ & $\begin{array}{c}0.0348 \\
(0.0310)\end{array}$ & $\begin{array}{c}0.0283 \\
(0.0345)\end{array}$ & $\begin{array}{c}0.0217 \\
(0.0301)\end{array}$ & $\begin{array}{c}0.0316 \\
(0.0318)\end{array}$ & $\begin{array}{c}0.0286 \\
(0.0314)\end{array}$ \\
\hline \# Observations & 1533 & 1469 & 1504 & 1442 & 1447 & 1533 & 1469 & 1504 & 1442 & 1447 \\
\hline \# Countries & 78 & 78 & 78 & 78 & 78 & 78 & 78 & 78 & 78 & 78 \\
\hline \# Instruments & 81 & 80 & 81 & 81 & 81 & 81 & 80 & 81 & 81 & 80 \\
\hline Hansen $J$-test & 0.1077 & 0.2891 & 0.2500 & 0.0818 & 0.0823 & 0.3956 & 0.3361 & 0.2990 & 0.4231 & 0.0784 \\
\hline $\operatorname{AR}(1)$ & 0.0000 & 0.0000 & 0.0000 & 0.0000 & 0.0000 & 0.0000 & 0.0000 & 0.0000 & 0.0000 & 0.0000 \\
\hline $\operatorname{AR}(2)$ & 0.2707 & 0.2434 & 0.3580 & 0.2139 & 0.2156 & 0.2692 & 0.2440 & 0.3654 & 0.2135 & 0.2072 \\
\hline
\end{tabular}

Notes: See Tables 1 to 3 in the paper. Robust standard errors are in parentheses; significance levels at which the null hypothesis is rejected: $* * *, 1 \%$; $* *, 5 \%$, and $*, 10 \%$. Year fixed-effects are controlled for in all estimations. A one step difference-GMM estimator is employed in the estimations and the instruments are collapsed. Election Gov change is a dummy variable that takes the value of one when there are elections that result in the change of the political orientation of the government; 0 otherwise. Before Election is equal to one in the years before the elections; 0 otherwise. After Election is equal to one in the years after the elections; 0 otherwise. Election timing measures the passage of the time between election (it is equal to one in the election years). 
Table A2. Presidential versus non-Presidential regimes

\begin{tabular}{|c|c|c|c|c|c|c|c|c|}
\hline & $(1)$ & $(2)$ & (3) & $(4)$ & $(5)$ & $(6)$ & $(7)$ & $(8)$ \\
\hline GWgrowth $_{t-1}$ & $\begin{array}{c}0.6085 * * * \\
(0.1636)\end{array}$ & $\begin{array}{c}0.3989 * * * \\
(0.1262)\end{array}$ & $\begin{array}{c}0.4970 * * * \\
(0.1741)\end{array}$ & $\begin{array}{c}0.4970 * * * \\
(0.1741)\end{array}$ & $\begin{array}{c}0.6049 * * * \\
(0.1593)\end{array}$ & $\begin{array}{c}0.3912 * * * \\
(0.1299)\end{array}$ & $\begin{array}{c}0.4871 * * * \\
(0.1739)\end{array}$ & $\begin{array}{c}0.4871 * * * \\
(0.1739)\end{array}$ \\
\hline Right & $\begin{array}{c}0.0924 \\
(0.0814)\end{array}$ & $\begin{array}{c}0.1717 * * \\
(0.0676)\end{array}$ & $\begin{array}{c}0.1996^{* *} \\
(0.0944)\end{array}$ & & & & & \\
\hline Right $*$ Presid & & & & $\begin{array}{c}0.1996 * * \\
(0.0944)\end{array}$ & & & & \\
\hline Right*NPresid & & & $\begin{array}{l}-0.0861 \\
(0.1225)\end{array}$ & $\begin{array}{l}0.1135^{*} \\
(0.0646)\end{array}$ & & & & \\
\hline Party tenure & $\begin{array}{c}0.0044 \\
(0.0045)\end{array}$ & $\begin{array}{l}-0.0055 \\
(0.0126)\end{array}$ & $\begin{array}{l}-0.0010 \\
(0.0061)\end{array}$ & $\begin{array}{l}-0.0010 \\
(0.0061)\end{array}$ & & & & \\
\hline $\begin{array}{l}\text { Right } * \text { Party tenure } \\
(\text { Right } * \text { Party tenure })^{\wedge} 2\end{array}$ & & & & & $\begin{array}{l}0.0229 \\
(0.0177) \\
-0.0005 \\
(0.0004)\end{array}$ & $\begin{array}{l}0.0320^{*} \\
(0.0180) \\
-0.0005 \\
(0.0005)\end{array}$ & $\begin{array}{c}0.0510 * * \\
(0.0252) \\
-0.0011 * * \\
(0.0005)\end{array}$ & \\
\hline Right*Presid*tenure & & & & & & & & $\begin{array}{c}0.0510^{* *} \\
(0.0252)\end{array}$ \\
\hline$\left(\text { Right }^{*} \text { Presid } * \text { tenure }\right)^{\wedge} 2$ & & & & & & & & $\begin{array}{c}-0.0011 * * \\
(0.0005)\end{array}$ \\
\hline Right*NPresid*tenure & & & & & & & $\begin{array}{l}-0.0416 \\
(0.0308)\end{array}$ & $\begin{array}{c}0.0094 \\
(0.0119)\end{array}$ \\
\hline$\left(\text { Right }^{*} N \text { Presid }{ }^{*} \text { tenure }\right)^{\wedge} 2$ & & & & & & & $\begin{array}{c}0.0012 \\
(0.0008)\end{array}$ & $\begin{array}{c}0.0001 \\
(0.0004)\end{array}$ \\
\hline Election year & $\begin{array}{c}0.0486 \\
(0.0485)\end{array}$ & $\begin{array}{c}0.0223 \\
(0.0409)\end{array}$ & $\begin{array}{c}0.0319 \\
(0.0327)\end{array}$ & $\begin{array}{c}0.0319 \\
(0.0327)\end{array}$ & $\begin{array}{c}0.0478 \\
(0.0488)\end{array}$ & $\begin{array}{l}-0.0004 \\
(0.0401)\end{array}$ & $\begin{array}{c}0.0197 \\
(0.0318)\end{array}$ & $\begin{array}{c}0.0197 \\
(0.0318)\end{array}$ \\
\hline Gov consumption & $\begin{array}{l}-0.0341 * \\
(0.0183)\end{array}$ & $\begin{array}{c}-0.1036 * * * \\
(0.0162)\end{array}$ & $\begin{array}{c}-0.0481 * * \\
(0.0217)\end{array}$ & $\begin{array}{c}-0.0481 * * \\
(0.0217)\end{array}$ & $\begin{array}{l}-0.0341 * \\
(0.0181)\end{array}$ & $\begin{array}{c}-0.1011 * * * \\
(0.0193)\end{array}$ & $\begin{array}{c}-0.0484 * * \\
(0.0218)\end{array}$ & $\begin{array}{c}-0.0484 * * \\
(0.0218)\end{array}$ \\
\hline Years Schooling & $\begin{array}{l}-0.2022 \\
(0.2466)\end{array}$ & $\begin{array}{c}0.2104 \\
(0.1662)\end{array}$ & $\begin{array}{l}-0.0307 \\
(0.1375)\end{array}$ & $\begin{array}{l}-0.0307 \\
(0.1375)\end{array}$ & $\begin{array}{l}-0.2001 \\
(0.2435)\end{array}$ & $\begin{array}{c}0.2710 \\
(0.1676)\end{array}$ & $\begin{array}{l}-0.0245 \\
(0.1365)\end{array}$ & $\begin{array}{l}-0.0245 \\
(0.1365)\end{array}$ \\
\hline LnGDP per capita & $\begin{array}{c}1.1932 \\
(0.8839)\end{array}$ & $\begin{array}{c}0.8780 \\
(0.7370)\end{array}$ & $\begin{array}{c}1.8501 * * * \\
(0.6308)\end{array}$ & $\begin{array}{c}1.8501 * * * \\
(0.6308)\end{array}$ & $\begin{array}{c}1.2271 \\
(0.8919)\end{array}$ & $\begin{array}{c}0.9413 \\
(0.7639)\end{array}$ & $\begin{array}{c}1.8351 * * * \\
(0.6269)\end{array}$ & $\begin{array}{c}1.8351 * * * \\
(0.6269)\end{array}$ \\
\hline Trade openness & $\begin{array}{l}-0.0119 \\
(0.0086)\end{array}$ & $\begin{array}{c}0.0048 \\
(0.0061)\end{array}$ & $\begin{array}{l}-0.0075 \\
(0.0068)\end{array}$ & $\begin{array}{l}-0.0075 \\
(0.0068)\end{array}$ & $\begin{array}{l}-0.0117 \\
(0.0085)\end{array}$ & $\begin{array}{c}0.0044 \\
(0.0063)\end{array}$ & $\begin{array}{l}-0.0073 \\
(0.0068)\end{array}$ & $\begin{array}{l}-0.0073 \\
(0.0068)\end{array}$ \\
\hline Urban pop ratio & $\begin{array}{l}-0.0236 \\
(0.0413)\end{array}$ & $\begin{array}{l}0.0951 * \\
(0.0506)\end{array}$ & $\begin{array}{c}0.0364 \\
(0.0305)\end{array}$ & $\begin{array}{c}0.0364 \\
(0.0305)\end{array}$ & $\begin{array}{l}-0.0222 \\
(0.0413)\end{array}$ & $\begin{array}{l}0.0950 * \\
(0.0495)\end{array}$ & $\begin{array}{c}0.0342 \\
(0.0303)\end{array}$ & $\begin{array}{c}0.0342 \\
(0.0303)\end{array}$ \\
\hline \# Observations & 740 & 757 & 1533 & 1533 & 740 & 757 & 1533 & 1533 \\
\hline \# Countries & 40 & 36 & 78 & 78 & 40 & 36 & 78 & 78 \\
\hline \# Instruments & 81 & 81 & 82 & 82 & 81 & 81 & 83 & 83 \\
\hline Hansen $J$-test & 1.0000 & 1.0000 & 0.2888 & 0.4154 & 1.0000 & 1.0000 & 0.5468 & 0.5468 \\
\hline $\operatorname{AR}(1)$ & 0.0003 & 0.0045 & 0.0000 & 0.0000 & 0.0003 & 0.0057 & 0.0000 & 0.0000 \\
\hline $\operatorname{AR}(2)$ & 0.3851 & 0.1573 & 0.2648 & 0.2648 & 0.4070 & 0.2048 & 0.2663 & 0.2663 \\
\hline
\end{tabular}

Notes: See Tables 1 to 3 in the paper. Robust standard errors are in parentheses; significance levels at which the null hypothesis is rejected: $* * *, 1 \%$; $* *, 5 \%$, and $*, 10 \%$. Year fixed-effects are controlled for in all estimations. A one step difference-GMM estimator is employed in the estimations and the instruments are collapsed. Presid (NPresid) is a dummy variable that takes the value of one in countries with presidential (non-presidential) regimes; 0 otherwise. 
Table A3. Plurality versus non-Plurality regimes

\begin{tabular}{|c|c|c|c|c|c|c|c|c|}
\hline & $(1)$ & $(2)$ & $(3)$ & $(4)$ & $(5)$ & (6) & $(7)$ & $(8)$ \\
\hline GWgrowth $_{t-1}$ & $\begin{array}{c}0.1746 \\
(0.2213)\end{array}$ & $\begin{array}{c}0.7099 * * * \\
(0.0954)\end{array}$ & $\begin{array}{c}0.4569 * * * \\
(0.1723)\end{array}$ & $\begin{array}{c}0.4569 * * * \\
(0.1723)\end{array}$ & $\begin{array}{c}0.1672 \\
(0.2208)\end{array}$ & $\begin{array}{c}0.7010 * * * \\
(0.0924)\end{array}$ & $\begin{array}{c}0.4450 * * \\
(0.1742)\end{array}$ & $\begin{array}{c}0.4450 * * \\
(0.1742)\end{array}$ \\
\hline Right & $\begin{array}{l}0.1242 * \\
(0.0652)\end{array}$ & $\begin{array}{c}0.1216 \\
(0.0893)\end{array}$ & $\begin{array}{c}0.1864 * * \\
(0.0757)\end{array}$ & & & & & \\
\hline Right*Plural & & & & $\begin{array}{c}0.1864 * * \\
(0.0757)\end{array}$ & & & & \\
\hline Right*NPural & & & $\begin{array}{l}-0.0952 \\
(0.1175)\end{array}$ & $\begin{array}{c}0.0912 \\
(0.0762)\end{array}$ & & & & \\
\hline Party tenure & $\begin{array}{l}-0.0007 \\
(0.0109)\end{array}$ & $\begin{array}{l}-0.0062 \\
(0.0071)\end{array}$ & $\begin{array}{l}-0.0006 \\
(0.0062)\end{array}$ & $\begin{array}{l}-0.0006 \\
(0.0062)\end{array}$ & & & & \\
\hline Right $*$ Party tenure & & & & & $\begin{array}{c}0.0215 \\
(0.0170)\end{array}$ & $\begin{array}{c}0.0170 \\
(0.0115)\end{array}$ & $\begin{array}{l}0.0385^{*} \\
(0.0226)\end{array}$ & \\
\hline$(\text { Right } * \text { Party tenure })^{\wedge} 2$ & & & & & $\begin{array}{c}0.0003 \\
(0.0007)\end{array}$ & $\begin{array}{c}-0.0005 * * \\
(0.0002)\end{array}$ & $\begin{array}{l}-0.0007 \\
(0.0005)\end{array}$ & \\
\hline Right*Plural*tenure & & & & & & & & $\begin{array}{l}0.0385^{*} \\
(0.0226)\end{array}$ \\
\hline$\left(\text { Right*Plural }{ }^{*} \text { tenure }\right)^{\wedge} 2$ & & & & & & & & $\begin{array}{l}-0.0007 \\
(0.0005)\end{array}$ \\
\hline Right*NPlural*tenure & & & & & & & $\begin{array}{l}-0.0197 \\
(0.0274)\end{array}$ & $\begin{array}{c}0.0188 \\
(0.0117)\end{array}$ \\
\hline$(\text { Right } * N P l u r a l * \text { tenure })^{\wedge} 2$ & & & & & & & $\begin{array}{c}0.0002 \\
(0.0006)\end{array}$ & $\begin{array}{c}-0.0005^{*} \\
(0.0002)\end{array}$ \\
\hline Election year & $\begin{array}{c}0.0234 \\
(0.0495)\end{array}$ & $\begin{array}{c}0.0993 * * \\
(0.0506)\end{array}$ & $\begin{array}{c}0.0312 \\
(0.0320)\end{array}$ & $\begin{array}{c}0.0312 \\
(0.0320)\end{array}$ & $\begin{array}{c}0.0073 \\
(0.0463)\end{array}$ & $\begin{array}{l}0.0895 * \\
(0.0489)\end{array}$ & $\begin{array}{c}0.0187 \\
(0.0311)\end{array}$ & $\begin{array}{c}0.0187 \\
(0.0311)\end{array}$ \\
\hline Gov consumption & $\begin{array}{c}-0.0541 * * \\
(0.0244)\end{array}$ & $\begin{array}{c}-0.0595 * * * \\
(0.0230)\end{array}$ & $\begin{array}{c}-0.0459 * * \\
(0.0216)\end{array}$ & $\begin{array}{c}-0.0459 * * \\
(0.0216)\end{array}$ & $\begin{array}{c}-0.0538 * * \\
(0.0240)\end{array}$ & $\begin{array}{c}-0.0598 * * * \\
(0.0226)\end{array}$ & $\begin{array}{c}-0.0459 * * \\
(0.0216)\end{array}$ & $\begin{array}{c}-0.0459 * * \\
(0.0216)\end{array}$ \\
\hline Years Schooling & $\begin{array}{l}-0.2363 \\
(0.2799)\end{array}$ & $\begin{array}{l}-0.0017 \\
(0.2088)\end{array}$ & $\begin{array}{l}-0.0395 \\
(0.1380)\end{array}$ & $\begin{array}{l}-0.0395 \\
(0.1380)\end{array}$ & $\begin{array}{l}-0.2064 \\
(0.2754)\end{array}$ & $\begin{array}{l}-0.0037 \\
(0.2137)\end{array}$ & $\begin{array}{l}-0.0269 \\
(0.1390)\end{array}$ & $\begin{array}{l}-0.0269 \\
(0.1390)\end{array}$ \\
\hline LnGDP per capita & $\begin{array}{c}2.0856^{* *} \\
(0.8811)\end{array}$ & $\begin{array}{l}1.9007 * * \\
(0.9671)\end{array}$ & $\begin{array}{c}1.9648 * * * \\
(0.6498)\end{array}$ & $\begin{array}{c}1.9648 * * * \\
(0.6498)\end{array}$ & $\begin{array}{c}2.1358 * * \\
(0.8939)\end{array}$ & $\begin{array}{l}1.8319 * \\
(0.9431)\end{array}$ & $\begin{array}{c}1.9896 * * * \\
(0.6555)\end{array}$ & $\begin{array}{c}1.9896 * * * \\
(0.6555)\end{array}$ \\
\hline Trade openness & $\begin{array}{c}-0.0071 * * \\
(0.0036)\end{array}$ & $\begin{array}{l}-0.0074 \\
(0.0129)\end{array}$ & $\begin{array}{l}-0.0069 \\
(0.0066)\end{array}$ & $\begin{array}{l}-0.0069 \\
(0.0066)\end{array}$ & $\begin{array}{l}-0.0066^{*} \\
(0.0035)\end{array}$ & $\begin{array}{l}-0.0075 \\
(0.0128)\end{array}$ & $\begin{array}{l}-0.0066 \\
(0.0066)\end{array}$ & $\begin{array}{l}-0.0066 \\
(0.0066)\end{array}$ \\
\hline Urban pop ratio & $\begin{array}{c}0.0395 \\
(0.0588)\end{array}$ & $\begin{array}{c}0.0608 * * \\
(0.0253)\end{array}$ & $\begin{array}{c}0.0392 \\
(0.0313)\end{array}$ & $\begin{array}{c}0.0392 \\
(0.0313)\end{array}$ & $\begin{array}{c}0.0379 \\
(0.0593)\end{array}$ & $\begin{array}{c}0.0590 * * \\
(0.0252)\end{array}$ & $\begin{array}{c}0.0371 \\
(0.0316)\end{array}$ & $\begin{array}{c}0.0371 \\
(0.0316)\end{array}$ \\
\hline \# Observations & 771 & 690 & 1525 & 1525 & 771 & 690 & 1525 & 1525 \\
\hline \# Countries & 38 & 35 & 77 & 77 & 38 & 35 & 77 & 77 \\
\hline \# Instruments & 81 & 81 & 82 & 82 & 81 & 81 & 83 & 83 \\
\hline Hansen $J$-test & 1.0000 & 1.0000 & 0.8764 & 0.8764 & 1.0000 & 1.0000 & 0.3361 & 0.3361 \\
\hline $\operatorname{AR}(1)$ & 0.0007 & 0.0043 & 0.0000 & 0.0000 & 0.0007 & 0.0044 & 0.0000 & 0.0000 \\
\hline $\operatorname{AR}(2)$ & 0.0762 & 0.1515 & 0.3512 & 0.3512 & 0.0735 & 0.1469 & 0.3535 & 0.3535 \\
\hline
\end{tabular}

Notes: See Tables 1 to 3 in the paper. Robust standard errors are in parentheses; significance levels at which the null hypothesis is rejected: $* * *, 1 \%$; $* *, 5 \%$, and *, $10 \%$. Year fixed-effects are controlled for in all estimations. A one step difference-GMM estimator is employed in the estimations and the instruments are collapsed. Plural (NPlural) is a dummy variable that takes the value of one in countries with plurality (non-plurality) regimes; 0 otherwise. 
Table A4. Proportional representation versus majority representation systems

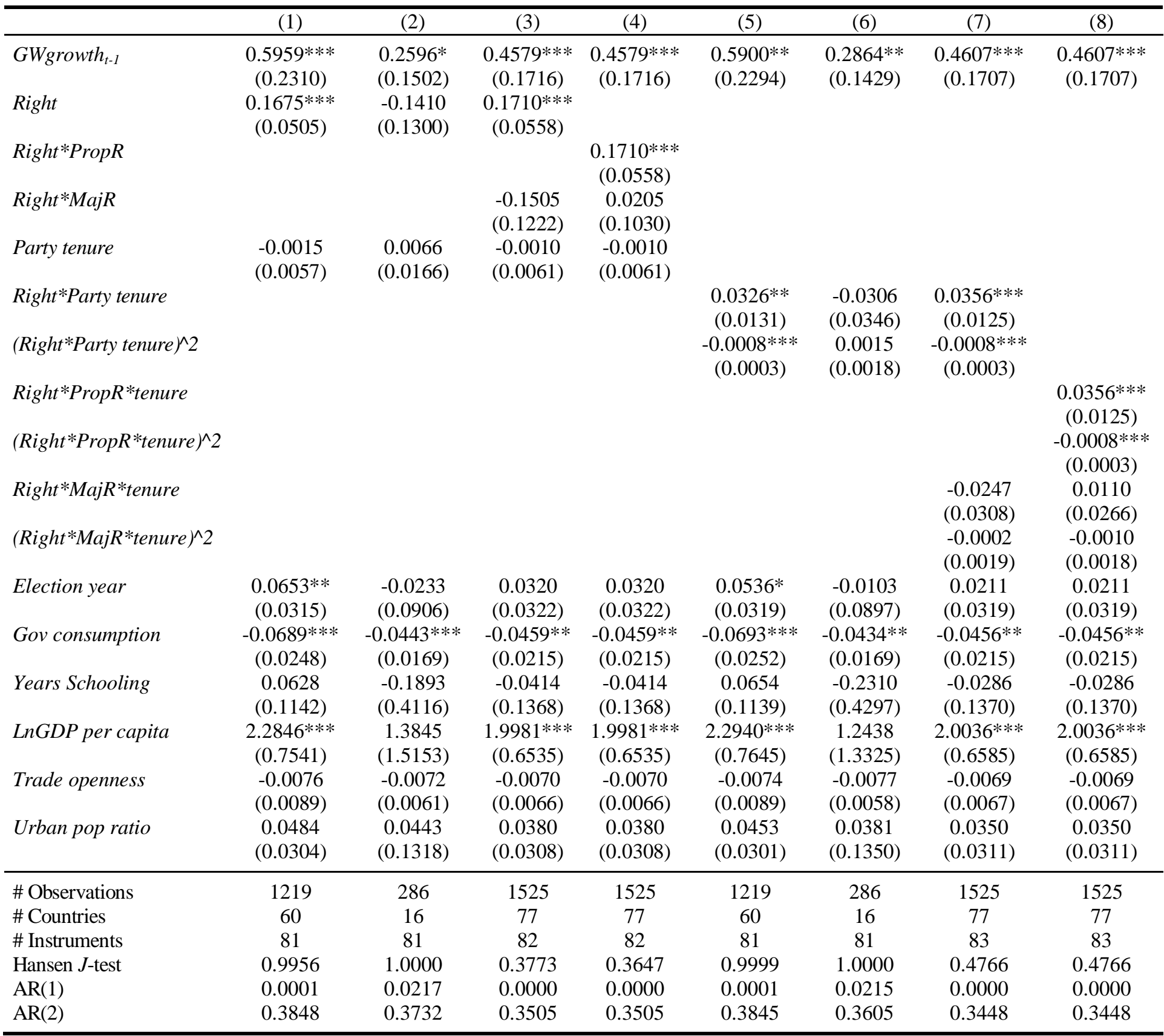

Notes: See Tables 1 to 3 in the paper. Robust standard errors are in parentheses; significance levels at which the null hypothesis is rejected: $* * *, 1 \%$; $* *, 5 \%$, and *, $10 \%$. Year fixed-effects are controlled for in all estimations. A one step difference-GMM estimator is employed in the estimations and the instruments are collapsed. PropR (MajR) is a dummy variable that takes the value of one in countries with proportional (majority) representation systems; 0 otherwise. 
Table A5. Sensitivity Analysis

\begin{tabular}{|c|c|c|c|c|c|c|c|c|}
\hline & (1) & $(2)$ & (3) & (4) & (5) & (6) & (7) & $(8)$ \\
\hline GWgrowth $_{t-1}$ & $\begin{array}{c}0.4680 * * * \\
(0.1726)\end{array}$ & $\begin{array}{c}0.3860 * * * \\
(0.1446)\end{array}$ & $\begin{array}{c}0.3912 * * * \\
(0.1461)\end{array}$ & $\begin{array}{c}0.4921 * * * \\
(0.1716)\end{array}$ & $\begin{array}{c}0.4650 * * * \\
(0.1715)\end{array}$ & $\begin{array}{c}0.3801 * * * \\
(0.1436)\end{array}$ & $\begin{array}{c}0.3854 * * * \\
(0.1451)\end{array}$ & $\begin{array}{c}0.4860 * * * \\
(0.1711)\end{array}$ \\
\hline Right & $\begin{array}{c}0.1094 * * \\
(0.0479)\end{array}$ & $\begin{array}{c}0.1323 * * * \\
(0.0459)\end{array}$ & $\begin{array}{c}0.1302 * * * \\
(0.0460)\end{array}$ & $\begin{array}{c}0.1446 * * * \\
(0.0481)\end{array}$ & & & & \\
\hline Party tenure & $\begin{array}{c}0.0062 \\
(0.0039)\end{array}$ & $\begin{array}{c}0.0008 \\
(0.0051)\end{array}$ & $\begin{array}{c}0.0006 \\
(0.0054)\end{array}$ & $\begin{array}{l}-0.0017 \\
(0.0059)\end{array}$ & & & & \\
\hline Right*Party tenure & & & & & $\begin{array}{c}0.0272 * * \\
(0.0113)\end{array}$ & $\begin{array}{c}0.0290 * * * \\
(0.0107)\end{array}$ & $\begin{array}{c}0.0280 * * * \\
(0.0106)\end{array}$ & $\begin{array}{c}0.0292 * * \\
(0.0113)\end{array}$ \\
\hline$\left(\text { Right }{ }^{*} \text { Party tenure }\right)^{\wedge} 2$ & & & & & $\begin{array}{c}-0.0006 * * \\
(0.0002)\end{array}$ & $\begin{array}{c}-0.0006 * * * \\
(0.0002)\end{array}$ & $\begin{array}{c}-0.0006 * * * \\
(0.0002)\end{array}$ & $\begin{array}{c}-0.0007 * * * \\
(0.0003)\end{array}$ \\
\hline Election year & $\begin{array}{c}0.0260 \\
(0.0321)\end{array}$ & $\begin{array}{c}0.0223 \\
(0.0307)\end{array}$ & $\begin{array}{c}0.0250 \\
(0.0314)\end{array}$ & $\begin{array}{c}0.0308 \\
(0.0323)\end{array}$ & $\begin{array}{c}0.0242 \\
(0.0319)\end{array}$ & $\begin{array}{c}0.0132 \\
(0.0301)\end{array}$ & $\begin{array}{c}0.0159 \\
(0.0308)\end{array}$ & $\begin{array}{c}0.0188 \\
(0.0317)\end{array}$ \\
\hline Majority & $\begin{array}{c}0.0561 \\
(0.0527)\end{array}$ & & & & $\begin{array}{c}0.0558 \\
(0.0535)\end{array}$ & & & \\
\hline Coalition & $\begin{array}{c}0.0807 \\
(0.0841)\end{array}$ & & & & $\begin{array}{c}0.0647 \\
(0.0796)\end{array}$ & & & \\
\hline Gov consumption & $\begin{array}{c}-0.0429 * * \\
(0.0198)\end{array}$ & $\begin{array}{c}-0.0414 * * \\
(0.0201)\end{array}$ & $\begin{array}{c}-0.0425^{* *} * \\
(0.0205)\end{array}$ & $\begin{array}{c}-0.0467 * * \\
(0.0208)\end{array}$ & $\begin{array}{c}-0.0427 * * \\
(0.0196)\end{array}$ & $\begin{array}{c}-0.0411 * * \\
(0.0199)\end{array}$ & $\begin{array}{c}-0.0423^{* *} * \\
(0.0204)\end{array}$ & $\begin{array}{c}-0.0467 * * \\
(0.0208)\end{array}$ \\
\hline Years Schooling & $\begin{array}{l}-0.0204 \\
(0.1347)\end{array}$ & $\begin{array}{l}-0.0063 \\
(0.1287)\end{array}$ & $\begin{array}{l}-0.0046 \\
(0.1290)\end{array}$ & $\begin{array}{l}-0.0071 \\
(0.1332)\end{array}$ & $\begin{array}{l}-0.0153 \\
(0.1352)\end{array}$ & $\begin{array}{c}0.0046 \\
(0.1281)\end{array}$ & $\begin{array}{c}0.0067 \\
(0.1284)\end{array}$ & $\begin{array}{c}0.0058 \\
(0.1329)\end{array}$ \\
\hline LnGDP per capita & $\begin{array}{c}1.7316^{* * * *} \\
(0.6228)\end{array}$ & & & $\begin{array}{c}2.1922 * * * \\
(0.7258)\end{array}$ & $\begin{array}{c}1.7568 * * * \\
(0.6317)\end{array}$ & & & $\begin{array}{c}2.1948 * * * \\
(0.7283)\end{array}$ \\
\hline GDPpc growth & & $\begin{array}{c}0.0406 * * * \\
(0.0124)\end{array}$ & & & & $\begin{array}{c}0.0407 * * * \\
(0.0125)\end{array}$ & & \\
\hline GDP growth & & & $\begin{array}{c}0.0299 * * \\
(0.0120)\end{array}$ & & & & $\begin{array}{c}0.0300 * * \\
(0.0121)\end{array}$ & \\
\hline Trade openness & $\begin{array}{l}-0.0060 \\
(0.0069)\end{array}$ & $\begin{array}{l}-0.0089 \\
(0.0070)\end{array}$ & $\begin{array}{l}-0.0087 \\
(0.0070)\end{array}$ & $\begin{array}{l}-0.0071 \\
(0.0067)\end{array}$ & $\begin{array}{l}-0.0058 \\
(0.0069)\end{array}$ & $\begin{array}{l}-0.0087 \\
(0.0070)\end{array}$ & $\begin{array}{l}-0.0085 \\
(0.0070)\end{array}$ & $\begin{array}{l}-0.0069 \\
(0.0067)\end{array}$ \\
\hline Urban pop ratio & $\begin{array}{c}0.0315 \\
(0.0306)\end{array}$ & $\begin{array}{c}0.0367 \\
(0.0283)\end{array}$ & $\begin{array}{c}0.0380 \\
(0.0290)\end{array}$ & & $\begin{array}{c}0.0317 \\
(0.0306)\end{array}$ & $\begin{array}{c}0.0353 \\
(0.0285)\end{array}$ & $\begin{array}{c}0.0366 \\
(0.0291)\end{array}$ & \\
\hline$\%$ Рор0-14 & & & & $\begin{array}{c}0.0408 \\
(0.0460)\end{array}$ & & & & $\begin{array}{c}0.0423 \\
(0.0468)\end{array}$ \\
\hline \%Pop65above & & & & $\begin{array}{l}-0.1546 \\
(0.0950)\end{array}$ & & & & $\begin{array}{l}-0.1473 \\
(0.0940)\end{array}$ \\
\hline \# Observations & 1520 & 1537 & 1537 & 1533 & 1520 & 1537 & 1537 & 1533 \\
\hline \# Countries & 78 & 79 & 79 & 78 & 78 & 79 & 79 & 78 \\
\hline \# Instruments & 83 & 81 & 81 & 82 & 83 & 81 & 81 & 82 \\
\hline Hansen $J$-test & 0.5029 & 0.1549 & 0.1723 & 0.3261 & 0.5620 & 0.1919 & 0.1731 & 0.4582 \\
\hline $\mathrm{AR}(1)$ & 0.0000 & 0.0000 & 0.0000 & 0.0000 & 0.0000 & 0.0000 & 0.0000 & 0.0000 \\
\hline $\operatorname{AR}(2)$ & 0.2968 & 0.3907 & 0.3700 & 0.2646 & 0.3023 & 0.4016 & 0.3780 & 0.2646 \\
\hline
\end{tabular}

Notes: See Tables 1 to 3 in the paper. Robust standard errors are in parentheses; significance levels at which the null hypothesis is rejected: $* * *, 1 \%$; $* *, 5 \%$, and $*, 10 \%$. Year fixed-effects are controlled for in all estimations. A one step difference-GMM estimator is employed in the estimations and the instruments are collapsed. Majority is a dummy variable that takes the value of one when the government has majority in the parliament; 0 otherwise. Coalition is a dummy variable that takes the value of one when the government is formed by a coalition of parties; 0 otherwise. GDPpc growth is the real GDP per capita growth rate. GDP growth is the real GDP growth rate. \%Pop014 accounts for the percentage of population between 0 and 14 years old. \%Pop65above accounts for the percentage of population with 65 years or more. 
Table A6. The role of institutions

\begin{tabular}{|c|c|c|c|c|c|c|}
\hline & $(1)$ & $(2)$ & (3) & (4) & $(5)$ & $(6)$ \\
\hline GWgrowth $_{t-1}$ & $\begin{array}{c}0.4963 * * * \\
(0.1515)\end{array}$ & $\begin{array}{c}0.5133 * * * \\
(0.1451)\end{array}$ & $\begin{array}{c}0.5280 * * * \\
(0.1441)\end{array}$ & $\begin{array}{c}0.4885 * * * \\
(0.1499)\end{array}$ & $\begin{array}{c}0.5060 * * * \\
(0.1449)\end{array}$ & $\begin{array}{c}0.5209 * * * \\
(0.1438)\end{array}$ \\
\hline Right & $\begin{array}{c}0.1469 * * * \\
(0.0562)\end{array}$ & $\begin{array}{c}0.1423 * * \\
(0.0581)\end{array}$ & $\begin{array}{c}0.1422 * * \\
(0.0576)\end{array}$ & & & \\
\hline Party tenure & $\begin{array}{c}0.0001 \\
(0.0063)\end{array}$ & $\begin{array}{c}0.0014 \\
(0.0068)\end{array}$ & $\begin{array}{c}0.0020 \\
(0.0064)\end{array}$ & & & \\
\hline Right*Party tenure & & & & $\begin{array}{c}0.0648 * * * \\
(0.0235)\end{array}$ & $\begin{array}{c}0.0332 * * \\
(0.0138)\end{array}$ & $\begin{array}{c}0.0353 * * \\
(0.0140)\end{array}$ \\
\hline$(\text { Right } * \text { Party tenure })^{\wedge} 2$ & & & & $\begin{array}{c}-0.0019 * * \\
(0.0009)\end{array}$ & $\begin{array}{c}-0.0007 * * \\
(0.0003)\end{array}$ & $\begin{array}{c}-0.0008 * * \\
(0.0003)\end{array}$ \\
\hline Election year & $\begin{array}{c}0.0388 \\
(0.0364)\end{array}$ & $\begin{array}{c}0.0294 \\
(0.0351)\end{array}$ & $\begin{array}{c}0.0317 \\
(0.0362)\end{array}$ & $\begin{array}{c}0.0203 \\
(0.0359)\end{array}$ & $\begin{array}{c}0.0187 \\
(0.0349)\end{array}$ & $\begin{array}{c}0.0217 \\
(0.0357)\end{array}$ \\
\hline Gov consumption & $\begin{array}{c}-0.0788 * * * \\
(0.0262)\end{array}$ & $\begin{array}{c}-0.0783 * * * \\
(0.0260)\end{array}$ & $\begin{array}{c}-0.0810 * * * \\
(0.0248)\end{array}$ & $\begin{array}{c}-0.0793 * * * \\
(0.0263)\end{array}$ & $\begin{array}{c}-0.0780 * * * \\
(0.0262)\end{array}$ & $\begin{array}{c}-0.0810 * * * \\
(0.0249)\end{array}$ \\
\hline Years Schooling & $\begin{array}{c}0.0194 \\
(0.1494)\end{array}$ & $\begin{array}{c}0.0198 \\
(0.1519)\end{array}$ & $\begin{array}{c}0.0300 \\
(0.1507)\end{array}$ & $\begin{array}{c}0.0340 \\
(0.1484)\end{array}$ & $\begin{array}{c}0.0333 \\
(0.1510)\end{array}$ & $\begin{array}{c}0.0438 \\
(0.1496)\end{array}$ \\
\hline LnGDP per capita & $\begin{array}{c}2.2967 * * * \\
(0.6525)\end{array}$ & $\begin{array}{c}2.6216^{* * *} * \\
(0.7519)\end{array}$ & $\begin{array}{c}2.4849 * * * \\
(0.7274)\end{array}$ & $\begin{array}{c}2.4013 * * * \\
(0.6835)\end{array}$ & $\begin{array}{c}2.6349 * * * \\
(0.7489)\end{array}$ & $\begin{array}{c}2.5166 * * * \\
(0.7311)\end{array}$ \\
\hline Trade openness & $\begin{array}{l}-0.0041 \\
(0.0072)\end{array}$ & $\begin{array}{l}-0.0044 \\
(0.0071)\end{array}$ & $\begin{array}{l}-0.0042 \\
(0.0070)\end{array}$ & $\begin{array}{l}-0.0038 \\
(0.0072)\end{array}$ & $\begin{array}{l}-0.0042 \\
(0.0072)\end{array}$ & $\begin{array}{l}-0.0040 \\
(0.0071)\end{array}$ \\
\hline Urban pop ratio & $\begin{array}{c}0.0425 \\
(0.0361)\end{array}$ & $\begin{array}{c}0.0354 \\
(0.0387)\end{array}$ & $\begin{array}{c}0.0415 \\
(0.0370)\end{array}$ & $\begin{array}{c}0.0414 \\
(0.0370)\end{array}$ & $\begin{array}{c}0.0348 \\
(0.0387)\end{array}$ & $\begin{array}{c}0.0408 \\
(0.0372)\end{array}$ \\
\hline FinRiskRating & $\begin{array}{c}0.0020 \\
(0.0087)\end{array}$ & & & $\begin{array}{l}-0.0002 \\
(0.0085)\end{array}$ & & \\
\hline PolRiskRating & $\begin{array}{l}-0.0067 \\
(0.0086)\end{array}$ & & & $\begin{array}{l}-0.0050 \\
(0.0089)\end{array}$ & & \\
\hline BureaucracyQual & & $\begin{array}{l}-0.0584 \\
(0.1016)\end{array}$ & & & $\begin{array}{l}-0.0591 \\
(0.1037)\end{array}$ & \\
\hline Corruption & & $\begin{array}{l}-0.0179 \\
(0.0456)\end{array}$ & & & $\begin{array}{l}-0.0136 \\
(0.0454)\end{array}$ & \\
\hline DemocAccountab & & $\begin{array}{l}0.1072 * \\
(0.0586)\end{array}$ & $\begin{array}{c}0.1116 * * \\
(0.0566)\end{array}$ & & $\begin{array}{l}0.1063^{*} \\
(0.0586)\end{array}$ & $\begin{array}{l}0.1105^{*} \\
(0.0565)\end{array}$ \\
\hline EthnicTensions & & $\begin{array}{c}-0.1501 * * * \\
(0.0550)\end{array}$ & $\begin{array}{c}-0.1329 * * \\
(0.0553)\end{array}$ & & $\begin{array}{c}-0.1503 * * * \\
(0.0553)\end{array}$ & $\begin{array}{c}-0.1338 * * \\
(0.0561)\end{array}$ \\
\hline ExternalConflict & & $\begin{array}{c}0.0628 \\
(0.0480)\end{array}$ & & & $\begin{array}{c}0.0619 \\
(0.0478)\end{array}$ & \\
\hline GovStability & & $\begin{array}{c}0.0031 \\
(0.0185)\end{array}$ & & & $\begin{array}{c}0.0046 \\
(0.0183)\end{array}$ & \\
\hline InternalConflict & & $\begin{array}{c}-0.0699 * * * \\
(0.0241)\end{array}$ & $\begin{array}{c}-0.0597 * * \\
(0.0238)\end{array}$ & & $\begin{array}{c}-0.0713 * * * \\
(0.0242)\end{array}$ & $\begin{array}{c}-0.0611 * * \\
(0.0240)\end{array}$ \\
\hline InvestProfile & & $\begin{array}{c}0.0109 \\
(0.0211)\end{array}$ & & & $\begin{array}{c}0.0103 \\
(0.0207)\end{array}$ & \\
\hline LawOrder & & $\begin{array}{l}-0.0129 \\
(0.0415)\end{array}$ & & & $\begin{array}{l}-0.0146 \\
(0.0426)\end{array}$ & \\
\hline ReligiousTensions & & $\begin{array}{c}0.0767 \\
(0.1116)\end{array}$ & & & $\begin{array}{c}0.0691 \\
(0.1103)\end{array}$ & \\
\hline SocEcoConditions & & $\begin{array}{c}-0.0328 \\
(0.0239)\end{array}$ & & & $\begin{array}{c}-0.0289 \\
(0.0238)\end{array}$ & \\
\hline \# Observations & 1394 & 1394 & 1394 & 1394 & 1394 & 1394 \\
\hline \# Countries & 76 & 76 & 76 & 76 & 76 & 76 \\
\hline \# Instruments & 79 & 88 & 80 & 79 & 88 & 80 \\
\hline Hansen $J$-test & 0.1751 & 0.9349 & 0.1588 & 0.3306 & 0.8176 & 0.3071 \\
\hline $\operatorname{AR}(1)$ & 0.0000 & 0.0001 & 0.0001 & 0.0000 & 0.0001 & 0.0001 \\
\hline $\mathrm{AR}(2)$ & 0.4881 & 0.5668 & 0.5330 & 0.5797 & 0.5918 & 0.5589 \\
\hline
\end{tabular}

Notes: See Tables 1 to 3 in the paper. Robust standard errors are in parentheses; significance levels at which the null hypothesis is rejected: $* * *, 1 \%$; $* *, 5 \%$, and $*, 10 \%$. Year fixed-effects are controlled for in all estimations. A one step difference-GMM estimator is employed in the estimations and the instruments are collapsed. Institutional variables data comes from the International Country Risk Guide ( see https://www.prsgroup.com/about-us/our-twomethodologies/icrg). 
Table A7. Robustness checks: OECD versus non-OECD countries

\begin{tabular}{|c|c|c|c|c|c|c|c|c|}
\hline & $\frac{(1)}{\text { OECD }}$ & $\frac{(2)}{\text { NOECD }}$ & $\frac{(3)}{\text { All }}$ & $\begin{array}{l}\text { (4) } \\
\text { All }\end{array}$ & $\frac{(5)}{\text { OECD }}$ & $\frac{(6)}{\text { NOECD }}$ & $\begin{array}{l}\text { (7) } \\
\text { All }\end{array}$ & $\frac{(8)}{\text { All }}$ \\
\hline GWrowth $_{t-1}$ & $\begin{array}{c}0.5553 * * * \\
(0.1033)\end{array}$ & $\begin{array}{c}0.3054 \\
(0.2098)\end{array}$ & $\begin{array}{c}0.4992 * * * \\
(0.1748)\end{array}$ & $\begin{array}{c}0.4992 * * * \\
(0.1748)\end{array}$ & $\begin{array}{c}0.5563 * * * \\
(0.0998)\end{array}$ & $\begin{array}{c}0.3004 \\
(0.2092)\end{array}$ & $\begin{array}{c}0.4830 * * * \\
(0.1749)\end{array}$ & $\begin{array}{c}0.4830 * * * \\
(0.1749)\end{array}$ \\
\hline Right & $\begin{array}{c}0.1326 * * * \\
(0.0491)\end{array}$ & $\begin{array}{c}0.2408 * * * \\
(0.0932)\end{array}$ & $\begin{array}{l}0.1069 * \\
(0.0546)\end{array}$ & & & & & \\
\hline Right* $O E C D$ & & & & $\begin{array}{l}0.1069^{*} \\
(0.0546)\end{array}$ & & & & \\
\hline Right*NOECD & & & $\begin{array}{c}0.1313 \\
(0.0982)\end{array}$ & $\begin{array}{c}0.2382 * * * \\
(0.0834)\end{array}$ & & & & \\
\hline Party tenure & $\begin{array}{l}0.0073^{*} \\
(0.0040)\end{array}$ & $\begin{array}{l}-0.0092 \\
(0.0104)\end{array}$ & $\begin{array}{c}0.0048 \\
(0.0039)\end{array}$ & & & & & \\
\hline Party tenure ${ }^{*} O E C D$ & & & & $\begin{array}{c}0.0048 \\
(0.0039)\end{array}$ & & & & \\
\hline Party tenure *NOECD & & & $\begin{array}{l}-0.0139 \\
(0.0122)\end{array}$ & $\begin{array}{l}-0.0090 \\
(0.0114)\end{array}$ & & & & \\
\hline Right $*$ Party tenure & & & & & $\begin{array}{c}0.0258 * * \\
(0.0106)\end{array}$ & $\begin{array}{c}0.0485 * * \\
(0.0233)\end{array}$ & $\begin{array}{c}0.0084 \\
(0.0119)\end{array}$ & \\
\hline$(\text { Right } * \text { Party tenure })^{\wedge} 2$ & & & & & $\begin{array}{l}-0.0005 \\
(0.0003)\end{array}$ & $\begin{array}{c}-0.0010 * * \\
(0.0005)\end{array}$ & $\begin{array}{c}0.0002 \\
(0.0005)\end{array}$ & \\
\hline Right*OECD*tenure & & & & & & & & $\begin{array}{c}0.0084 \\
(0.0119)\end{array}$ \\
\hline$(\text { Right } * O E C D * \text { tenure })^{\wedge} 2$ & & & & & & & & $\begin{array}{c}0.0002 \\
(0.0005)\end{array}$ \\
\hline Right*NOECD*tenure & & & & & & & $\begin{array}{c}0.0436 \\
(0.0321)\end{array}$ & $\begin{array}{l}0.0520^{*} \\
(0.0266)\end{array}$ \\
\hline$(\text { Right } * N O E C D * \text { tenure })^{\wedge} 2$ & & & & & & & $\begin{array}{l}-0.0014 \\
(0.0009)\end{array}$ & $\begin{array}{c}-0.0012 * * \\
(0.0006)\end{array}$ \\
\hline Election year & $\begin{array}{c}0.0503 \\
(0.0352)\end{array}$ & $\begin{array}{c}0.0265 \\
(0.0601)\end{array}$ & $\begin{array}{c}0.0307 \\
(0.0328)\end{array}$ & $\begin{array}{c}0.0307 \\
(0.0328)\end{array}$ & $\begin{array}{c}0.0487 \\
(0.0352)\end{array}$ & $\begin{array}{c}0.0027 \\
(0.0560)\end{array}$ & $\begin{array}{c}0.0184 \\
(0.0315)\end{array}$ & $\begin{array}{c}0.0184 \\
(0.0315)\end{array}$ \\
\hline Gov consumption & $\begin{array}{c}-0.1416 * * * \\
(0.0224)\end{array}$ & $\begin{array}{c}-0.0335 * * \\
(0.0158)\end{array}$ & $\begin{array}{c}-0.0478 * * \\
(0.0215)\end{array}$ & $\begin{array}{c}-0.0478 * * \\
(0.0215)\end{array}$ & $\begin{array}{c}-0.1392 * * * \\
(0.0227)\end{array}$ & $\begin{array}{c}-0.0347 * * \\
(0.0161)\end{array}$ & $\begin{array}{c}-0.0481 * * \\
(0.0216)\end{array}$ & $\begin{array}{c}-0.0481 * * \\
(0.0216)\end{array}$ \\
\hline Years Schooling & $\begin{array}{c}0.1166 \\
(0.1268)\end{array}$ & $\begin{array}{l}-0.4144 \\
(0.2873)\end{array}$ & $\begin{array}{l}-0.0308 \\
(0.1376)\end{array}$ & $\begin{array}{l}-0.0308 \\
(0.1376)\end{array}$ & $\begin{array}{c}0.1406 \\
(0.1253)\end{array}$ & $\begin{array}{l}-0.4217 \\
(0.2884)\end{array}$ & $\begin{array}{l}-0.0277 \\
(0.1367)\end{array}$ & $\begin{array}{l}-0.0277 \\
(0.1367)\end{array}$ \\
\hline LnGDP per capita & $\begin{array}{c}0.9244 \\
(0.7219)\end{array}$ & $\begin{array}{l}2.2268 * * \\
(0.9464)\end{array}$ & $\begin{array}{c}1.8512 * * * \\
(0.6307)\end{array}$ & $\begin{array}{c}1.8512 * * * \\
(0.6307)\end{array}$ & $\begin{array}{c}0.9981 \\
(0.7086)\end{array}$ & $\begin{array}{c}2.1964 * * \\
(0.9660)\end{array}$ & $\begin{array}{c}1.8267 * * * \\
(0.6308)\end{array}$ & $\begin{array}{c}1.8267 * * * \\
(0.6308)\end{array}$ \\
\hline Trade openness & $\begin{array}{c}0.0139 * * \\
(0.0055)\end{array}$ & $\begin{array}{c}-0.0161 * * \\
(0.0075)\end{array}$ & $\begin{array}{l}-0.0074 \\
(0.0068)\end{array}$ & $\begin{array}{l}-0.0074 \\
(0.0068)\end{array}$ & $\begin{array}{c}0.0142 * * \\
(0.0057)\end{array}$ & $\begin{array}{c}-0.0163 * * \\
(0.0076)\end{array}$ & $\begin{array}{l}-0.0074 \\
(0.0068)\end{array}$ & $\begin{array}{l}-0.0074 \\
(0.0068)\end{array}$ \\
\hline Urban pop ratio & $\begin{array}{c}0.0569 * * \\
(0.0278)\end{array}$ & $\begin{array}{c}0.0320 \\
(0.0466)\end{array}$ & $\begin{array}{c}0.0373 \\
(0.0304)\end{array}$ & $\begin{array}{c}0.0373 \\
(0.0304)\end{array}$ & $\begin{array}{c}0.0576 * * \\
(0.0273)\end{array}$ & $\begin{array}{c}0.0303 \\
(0.0466)\end{array}$ & $\begin{array}{c}0.0337 \\
(0.0310)\end{array}$ & $\begin{array}{c}0.0337 \\
(0.0310)\end{array}$ \\
\hline \# Observations & 789 & 744 & 1533 & 1533 & 789 & 744 & 1533 & 1533 \\
\hline \# Countries & 31 & 47 & 78 & 78 & 31 & 47 & 78 & 78 \\
\hline \# Instruments & 81 & 81 & 83 & 83 & 81 & 81 & 83 & 83 \\
\hline Hansen $J$-test & 1.0000 & 1.0000 & 0.4214 & 0.4214 & 1.0000 & 1.0000 & 0.4332 & 0.4332 \\
\hline $\operatorname{AR}(1)$ & 0.0026 & 0.0001 & 0.0000 & 0.0000 & 0.0024 & 0.0002 & 0.0000 & 0.0000 \\
\hline $\operatorname{AR}(2)$ & 0.2367 & 0.1496 & 0.2706 & 0.2706 & 0.2447 & 0.1383 & 0.2679 & 0.2679 \\
\hline
\end{tabular}

Notes: See Tables 1 to 3 in the paper. Robust standard errors are in parentheses; significance levels at which the null hypothesis is rejected: $* * *, 1 \%$; **, $5 \%$, and *, $10 \%$. Year fixed-effects are controlled for in all estimations. A one step difference-GMM estimator is employed in the estimations and the instruments are collapsed. OECD (NOECD) is a dummy variable that takes the value of one for OECD countries (non-OECD countries); 0 otherwise. 
Table A8. Robustness checks: High-income versus Low-income countries

\begin{tabular}{|c|c|c|c|c|c|c|c|c|}
\hline & $\frac{(1)}{\mathrm{HIC}}$ & $\frac{(2)}{\text { NHIC }}$ & $\frac{(3)}{\text { All }}$ & $\begin{array}{l}\text { (4) } \\
\text { All }\end{array}$ & $\frac{(5)}{\mathrm{HIC}}$ & $\frac{(6)}{\text { NHIC }}$ & $\begin{array}{l}\text { (7) } \\
\text { All }\end{array}$ & $\begin{array}{l}(8) \\
\text { All }\end{array}$ \\
\hline GWgrowth $_{t-1}$ & $\begin{array}{c}0.2137 \\
(0.2992)\end{array}$ & $\begin{array}{c}0.5254 * * * \\
(0.1330)\end{array}$ & $\begin{array}{c}0.5031 * * * \\
(0.1733)\end{array}$ & $\begin{array}{c}0.5031^{* * *} * \\
(0.1733)\end{array}$ & $\begin{array}{c}0.2018 \\
(0.3009)\end{array}$ & $\begin{array}{c}0.5162 * * * \\
(0.1352)\end{array}$ & $\begin{array}{c}0.4898 * * * \\
(0.1726)\end{array}$ & $\begin{array}{c}0.4898 * * * \\
(0.1726)\end{array}$ \\
\hline Right & $\begin{array}{c}0.1553 * * * \\
(0.0588)\end{array}$ & $\begin{array}{c}0.2127 * * \\
(0.0927)\end{array}$ & $\begin{array}{c}0.1550 * * \\
(0.0665)\end{array}$ & & & & & \\
\hline$R i g h t * H I C$ & & & & $\begin{array}{c}0.1550 * * \\
(0.0665)\end{array}$ & & & & \\
\hline Right*NHIC & & & $\begin{array}{c}0.0131 \\
(0.1215)\end{array}$ & $\begin{array}{l}0.1681^{*} \\
(0.0906)\end{array}$ & & & & \\
\hline Party tenure & $\begin{array}{l}0.0093 * \\
(0.0048)\end{array}$ & $\begin{array}{l}-0.0101 \\
(0.0103)\end{array}$ & $\begin{array}{c}0.0081 * * \\
(0.0041)\end{array}$ & & & & & \\
\hline Party tenure * HIC & & & & $\begin{array}{c}0.0081 * * \\
(0.0041)\end{array}$ & & & & \\
\hline Party tenure *NHIC & & & $\begin{array}{l}-0.0210 * \\
(0.0117)\end{array}$ & $\begin{array}{l}-0.0129 \\
(0.0113)\end{array}$ & & & & \\
\hline Right*Party tenure & & & & & $\begin{array}{l}0.0241 * \\
(0.0134)\end{array}$ & $\begin{array}{c}0.0340 \\
(0.0230)\end{array}$ & $\begin{array}{l}0.0244 * \\
(0.0136)\end{array}$ & \\
\hline$(\text { Right } * \text { Party tenure })^{\wedge} 2$ & & & & & $\begin{array}{c}0.0000 \\
(0.0007)\end{array}$ & $\begin{array}{l}-0.0007 \\
(0.0005)\end{array}$ & $\begin{array}{l}-0.0001 \\
(0.0005)\end{array}$ & \\
\hline Right* HIC *tenure & & & & & & & & $\begin{array}{l}0.0244 * \\
(0.0136)\end{array}$ \\
\hline$(\text { Right } * \text { HIC *tenure })^{\wedge} 2$ & & & & & & & & $\begin{array}{l}-0.0001 \\
(0.0005)\end{array}$ \\
\hline Right* NHIC *tenure & & & & & & & $\begin{array}{c}0.0037 \\
(0.0263)\end{array}$ & $\begin{array}{c}0.0281 \\
(0.0224)\end{array}$ \\
\hline$\left(\text { Right }^{*} \text { NHIC } * \text { tenure }\right)^{\wedge} 2$ & & & & & & & $\begin{array}{l}-0.0005 \\
(0.0007)\end{array}$ & $\begin{array}{l}-0.0007 \\
(0.0005)\end{array}$ \\
\hline Election year & $\begin{array}{c}0.0418 \\
(0.0295)\end{array}$ & $\begin{array}{l}-0.0098 \\
(0.0619)\end{array}$ & $\begin{array}{c}0.0313 \\
(0.0332)\end{array}$ & $\begin{array}{c}0.0313 \\
(0.0332)\end{array}$ & $\begin{array}{c}0.0387 \\
(0.0294)\end{array}$ & $\begin{array}{l}-0.0316 \\
(0.0605)\end{array}$ & $\begin{array}{c}0.0208 \\
(0.0324)\end{array}$ & $\begin{array}{c}0.0208 \\
(0.0324)\end{array}$ \\
\hline Gov consumption & $\begin{array}{c}-0.1022 * * * \\
(0.0347)\end{array}$ & $\begin{array}{c}-0.0407 * * \\
(0.0170)\end{array}$ & $\begin{array}{c}-0.0477 * * \\
(0.0215)\end{array}$ & $\begin{array}{c}-0.0477 * * \\
(0.0215)\end{array}$ & $\begin{array}{c}-0.1000 * * * \\
(0.0333)\end{array}$ & $\begin{array}{c}-0.0417 * * \\
(0.0173)\end{array}$ & $\begin{array}{c}-0.0478 * * \\
(0.0216)\end{array}$ & $\begin{array}{c}-0.0478 * * \\
(0.0216)\end{array}$ \\
\hline Years Schooling & $\begin{array}{c}0.1581 \\
(0.1663)\end{array}$ & $\begin{array}{l}-0.1263 \\
(0.3069)\end{array}$ & $\begin{array}{c}-0.0358 \\
(0.1392)\end{array}$ & $\begin{array}{l}-0.0358 \\
(0.1392)\end{array}$ & $\begin{array}{c}0.1756 \\
(0.1661)\end{array}$ & $\begin{array}{l}-0.1170 \\
(0.2973)\end{array}$ & $\begin{array}{l}-0.0235 \\
(0.1375)\end{array}$ & $\begin{array}{l}-0.0235 \\
(0.1375)\end{array}$ \\
\hline LnGDP per capita & $\begin{array}{l}1.9955 * * \\
(0.7832)\end{array}$ & $\begin{array}{c}2.2239 * * \\
(1.0755)\end{array}$ & $\begin{array}{c}1.8511 * * * \\
(0.6333)\end{array}$ & $\begin{array}{c}1.8511 * * * \\
(0.6333)\end{array}$ & $\begin{array}{c}2.0144 * * * \\
(0.7718)\end{array}$ & $\begin{array}{c}2.2891 * * \\
(1.0954)\end{array}$ & $\begin{array}{c}1.8491 * * * \\
(0.6365)\end{array}$ & $\begin{array}{c}1.8491 * * * \\
(0.6365)\end{array}$ \\
\hline Trade openness & $\begin{array}{c}0.0002 \\
(0.0086)\end{array}$ & $\begin{array}{l}-0.0146^{*} \\
(0.0076)\end{array}$ & $\begin{array}{l}-0.0072 \\
(0.0067)\end{array}$ & $\begin{array}{l}-0.0072 \\
(0.0067)\end{array}$ & $\begin{array}{c}0.0006 \\
(0.0085)\end{array}$ & $\begin{array}{l}-0.0148 * \\
(0.0078)\end{array}$ & $\begin{array}{l}-0.0072 \\
(0.0068)\end{array}$ & $\begin{array}{l}-0.0072 \\
(0.0068)\end{array}$ \\
\hline Urban pop ratio & $\begin{array}{c}0.0328 \\
(0.0407)\end{array}$ & $\begin{array}{c}0.0188 \\
(0.0507)\end{array}$ & $\begin{array}{c}0.0365 \\
(0.0301)\end{array}$ & $\begin{array}{c}0.0365 \\
(0.0301)\end{array}$ & $\begin{array}{c}0.0325 \\
(0.0408)\end{array}$ & $\begin{array}{c}0.0199 \\
(0.0508)\end{array}$ & $\begin{array}{c}0.0341 \\
(0.0308)\end{array}$ & $\begin{array}{c}0.0341 \\
(0.0308)\end{array}$ \\
\hline \# Observations & 870 & 663 & 1533 & 1533 & 870 & 663 & 1533 & 1533 \\
\hline \# Countries & 37 & 41 & 78 & 78 & 37 & 41 & 78 & 78 \\
\hline \# Instruments & 81 & 81 & 83 & 83 & 81 & 81 & 83 & 83 \\
\hline Hansen $J$-test & 1.0000 & 1.0000 & 0.6091 & 0.6091 & 1.0000 & 1.0000 & 0.5303 & 0.5303 \\
\hline $\mathrm{AR}(1)$ & 0.0006 & 0.0002 & 0.0000 & 0.0000 & 0.0006 & 0.0003 & 0.0000 & 0.0000 \\
\hline $\operatorname{AR}(2)$ & 0.2693 & 0.4381 & 0.2738 & 0.2738 & 0.2667 & 0.4007 & 0.2692 & 0.2692 \\
\hline
\end{tabular}

Notes: See Tables 1 to 3 in the paper. Robust standard errors are in parentheses; significance levels at which the null hypothesis is rejected: $* * *, 1 \%$; **, $5 \%$, and $*, 10 \%$. Year fixed-effects are controlled for in all estimations. A one step difference-GMM estimator is employed in the estimations and the instruments are collapsed. HIC (NHIC) is a dummy variable that takes the value of one for high-income countries (not high or low-income countries); 0 otherwise. 
Table A9. Robustness checks: time-periods

\begin{tabular}{|c|c|c|c|c|c|c|c|c|}
\hline & $(1)$ & $(2)$ & (3) & (4) & (5) & (6) & $(7)$ & $(8)$ \\
\hline & $\geq 1990$ & $\geq 2000$ & $\geq 1990$ & $\geq 2000$ & $\geq 1990$ & $\geq 2000$ & $\geq 1990$ & $\geq 2000$ \\
\hline GWgrowth $_{t-1}$ & $\begin{array}{l}0.4149^{*} \\
(0.2168)\end{array}$ & $\begin{array}{c}0.2221 \\
(0.1672)\end{array}$ & $\begin{array}{l}0.4171 * \\
(0.2174)\end{array}$ & $\begin{array}{c}0.2210 \\
(0.1680)\end{array}$ & $\begin{array}{l}0.4112^{*} \\
(0.2159)\end{array}$ & $\begin{array}{c}0.2371 \\
(0.1659)\end{array}$ & $\begin{array}{l}0.4132 * \\
(0.2173)\end{array}$ & $\begin{array}{c}0.2261 \\
(0.1687)\end{array}$ \\
\hline Right & $\begin{array}{c}0.1275 * * \\
(0.0535)\end{array}$ & $\begin{array}{c}0.0570 \\
(0.0799)\end{array}$ & $\begin{array}{c}0.1344 * * \\
(0.0537)\end{array}$ & $\begin{array}{c}0.0535 \\
(0.0812)\end{array}$ & & & & \\
\hline Party tenure & $\begin{array}{c}0.0003 \\
(0.0065)\end{array}$ & $\begin{array}{l}0.0068 * \\
(0.0038)\end{array}$ & & & & & & \\
\hline Right*Party tenure & & & & & $\begin{array}{c}0.0302 * * * \\
(0.0117)\end{array}$ & $\begin{array}{l}0.0337 * \\
(0.0172)\end{array}$ & & \\
\hline$\left(\text { Right }{ }^{*} \text { Party tenure }\right)^{\wedge} 2$ & & & & & $\begin{array}{c}-0.0006 * * * \\
(0.0002)\end{array}$ & $\begin{array}{c}-0.0007 * * \\
(0.0003)\end{array}$ & & \\
\hline Leader tenure & & & $\begin{array}{c}0.0043 \\
(0.0087)\end{array}$ & $\begin{array}{c}0.0008 \\
(0.0105)\end{array}$ & & & & \\
\hline Right*Leader tenure & & & & & & & $\begin{array}{l}0.0192^{*} \\
(0.0112)\end{array}$ & $\begin{array}{c}0.0157 \\
(0.0206)\end{array}$ \\
\hline Election year & $\begin{array}{c}0.0293 \\
(0.0357)\end{array}$ & $\begin{array}{c}0.0338 \\
(0.0430)\end{array}$ & $\begin{array}{c}0.0253 \\
(0.0339)\end{array}$ & $\begin{array}{c}0.0424 \\
(0.0415)\end{array}$ & $\begin{array}{c}0.0177 \\
(0.0348)\end{array}$ & $\begin{array}{c}0.0310 \\
(0.0424)\end{array}$ & $\begin{array}{c}0.0205 \\
(0.0330)\end{array}$ & $\begin{array}{c}0.0360 \\
(0.0406)\end{array}$ \\
\hline Gov consumption & $\begin{array}{l}-0.0576 \\
(0.0379)\end{array}$ & $\begin{array}{c}-0.0895 * * * \\
(0.0346)\end{array}$ & $\begin{array}{l}-0.0585 \\
(0.0379)\end{array}$ & $\begin{array}{c}-0.0891 * * * \\
(0.0345)\end{array}$ & $\begin{array}{l}-0.0580 \\
(0.0380)\end{array}$ & $\begin{array}{c}-0.0904 * * * \\
(0.0348)\end{array}$ & $\begin{array}{l}-0.0588 \\
(0.0379)\end{array}$ & $\begin{array}{c}-0.0888 * * * \\
(0.0344)\end{array}$ \\
\hline Years Schooling & $\begin{array}{l}-0.0888 \\
(0.1500)\end{array}$ & $\begin{array}{c}0.0577 \\
(0.2199)\end{array}$ & $\begin{array}{l}-0.0945 \\
(0.1535)\end{array}$ & $\begin{array}{c}0.0561 \\
(0.2209)\end{array}$ & $\begin{array}{l}-0.0757 \\
(0.1493)\end{array}$ & $\begin{array}{c}0.0705 \\
(0.2230)\end{array}$ & $\begin{array}{l}-0.0859 \\
(0.1545)\end{array}$ & $\begin{array}{c}0.0587 \\
(0.2238)\end{array}$ \\
\hline LnGDP per capita & $\begin{array}{c}2.1061 * * \\
(0.9080)\end{array}$ & $\begin{array}{c}2.0623 * * \\
(0.9772)\end{array}$ & $\begin{array}{c}2.0815 * * \\
(0.9026)\end{array}$ & $\begin{array}{c}2.1354 * * \\
(0.9985)\end{array}$ & $\begin{array}{c}2.1102 * * \\
(0.9000)\end{array}$ & $\begin{array}{c}2.1992 * * \\
(0.9893)\end{array}$ & $\begin{array}{c}2.0680 * * \\
(0.8950)\end{array}$ & $\begin{array}{l}2.1112 * * \\
(0.9731)\end{array}$ \\
\hline Trade openness & $\begin{array}{l}-0.0029 \\
(0.0050)\end{array}$ & $\begin{array}{c}0.0052 \\
(0.0063)\end{array}$ & $\begin{array}{l}-0.0028 \\
(0.0050)\end{array}$ & $\begin{array}{c}0.0051 \\
(0.0064)\end{array}$ & $\begin{array}{l}-0.0026 \\
(0.0050)\end{array}$ & $\begin{array}{c}0.0054 \\
(0.0064)\end{array}$ & $\begin{array}{l}-0.0027 \\
(0.0050)\end{array}$ & $\begin{array}{c}0.0054 \\
(0.0064)\end{array}$ \\
\hline Urban pop ratio & $\begin{array}{c}0.0234 \\
(0.0305)\end{array}$ & $\begin{array}{c}0.0312 \\
(0.0449)\end{array}$ & $\begin{array}{c}0.0207 \\
(0.0313)\end{array}$ & $\begin{array}{c}0.0337 \\
(0.0453)\end{array}$ & $\begin{array}{c}0.0233 \\
(0.0312)\end{array}$ & $\begin{array}{c}0.0314 \\
(0.0460)\end{array}$ & $\begin{array}{c}0.0212 \\
(0.0314)\end{array}$ & $\begin{array}{c}0.0329 \\
(0.0457)\end{array}$ \\
\hline \# Observations & 1234 & 743 & 1235 & 739 & 1234 & 743 & 1235 & 739 \\
\hline \# Countries & 77 & 74 & 77 & 74 & 77 & 74 & 77 & 74 \\
\hline \# Instruments & 72 & 62 & 72 & 62 & 72 & 62 & 71 & 61 \\
\hline Hansen $J$-test & 0.1530 & 0.2883 & 0.1876 & 0.3137 & 0.2002 & 0.2684 & 0.2322 & 0.2804 \\
\hline $\mathrm{AR}(1)$ & 0.0000 & 0.0035 & 0.0000 & 0.0034 & 0.0000 & 0.0040 & 0.0000 & 0.0034 \\
\hline $\operatorname{AR}(2)$ & 0.1494 & 0.5357 & 0.1476 & 0.5480 & 0.1503 & 0.5472 & 0.1461 & 0.5178 \\
\hline
\end{tabular}

Notes: See Tables 1 to 3 in the paper. Robust standard errors are in parentheses; significance levels at which the null hypothesis is rejected: ***, $1 \%$; **, $5 \%$, and *, 10\%. Year fixed-effects are controlled for in all estimations. A one step difference-GMM estimator is employed in the estimations and the instruments are collapsed. " $\geq 1990$ " indicates that the time period starts in 1990 ; " $\geq 2000$ " indicates that the time period starts in 1990. 


\section{Most Recent Working Paper}

NIPE WP $\quad$ Aidt, Toke S., Vitor Castro e Rodrigo Martins, "Shades of red and blue: Political ideology and 07/2016 sustainable development", 2016

NIPE WP Veiga, Linda Gonçalves e Francisco Veiga, “Term limits at the local government level”, 2016

$07 / 2016$

NIPE WP Castro, Vítor e Rodrigo Martins, "The Electoral Dynamics of Human Development”, 2016

06/2016

NIPE WP Bastos, Paulo, Natália P. Monteiro e Odd Rune Straume, "Foreign acquisition and internal 05/2016 organization", 2016

NIPE WP Esteves, Rosa-Branca, Qihong Liu e Jie Shuai, "Behavior-Based Price Discrimination in a 04/2016 Multi-Dimensional Preferences Market", 2016

NIPE WP Bleaney, Michael e Manuela Francisco, "Real Exchange Rate Volatility: Is Sub-Saharan Africa 03/2016 Different?", 2016

NIPE WP Castro, Vítor e Rodrigo Martins, "Politically driven cycles in fiscal policy: In depth analysis of 02/2016 the functional components of government expenditures", 2016

NIPE WP Bouchellal, Abdellah e Vítor Castro, "On the length of bank-firm relationships: An empirical 01/2016 application to a major French bank", 2016

NIPE WP Loureiro, Gilberto e Sónia Silva, "Post-Operating Performance Of Cross-Delisted Firms From 17/2015 U.S. Stock Exchanges", 2015

NIPE WP Loureiro, Gilberto e Sónia Silva, "Earnings Management and Stock Price Crashes Post 16/2015 Crossdelisting", 2015

NIPE WP Gilberto Loureiro e Sónia Silva, "Cross-Delisting, Financial Contraints and Investment

15/2015 Sensitivities", 2015

NIPE WP Fauver, Larry, Gilberto Loureiro e Alvaro G. Taboada, "Equity Offerings, Stock Price Crash 14/2015 Risk, and the Impact of Securities Regulation: International Evidence", 2015

NIPE WP Pereira, Paulo J. e Artur Rodrigues, “A theory on merger timing and announcement returns",

$13 / 2015 \quad 2015$

NIPE WP Bernardino, Susana e Santos, J. Freitas, "Financing social ventures by crowdfunding: The

$12 / 2015$ influence of entrepreneurs' personality traits", 2015

NIPE WP

$11 / 2015$

NIPE WP

$10 / 2015$

D’Almeida, André Corrêa e Paulo Reis Mourão, “ The Irrelevance of Political Parties'

Differences for Public Finances - Evidence from Public Deficit and Debt in Portugal (1974 2012)", 2015

NIPE WP

09/2015

NIPE WP

08/2015

Santos, José Freitas, Laurentina Vareiro, Paula Remoaldo e J. Cadima Ribeiro, "Mega cultural

events: Does attendance affect residents' perceptions of a city's identity?", 2015

NIPE WP Brekke, Kurt R., Tor Helge Holmås, Karin Monstad e Odd Rune Straume, "Do Treatment

07/2015 Decisions Depend on Physicians' Financial Incentives?”, 2015

NIPE WP Brekke, Kurt R., Chiara Canta e Odd Rune Straume, "Does Reference Pricing Drive Out

06/2015 Generic Competition in Pharmaceutical Markets? Evidence from a Policy Reform”, 2015

NIPE WP $\quad$ Brekke, Kurt R., Tor Helge Holmäs, Karin Monstad e Odd Rune Straume, "Socioeconomic

$05 / 2015$

NIPE WP

$04 / 2015$

NIPE WP

03/2015

NIPE WP

$02 / 2015$

NIPE WP

$01 / 2015$

Status and Physicians`Treatment Decisions”, 2015

Castro, Vítor e Rodrigo Martins, "Budget, expenditures composition and political manipulation:

Evidence from Portugal", 2015

Maria Thompson, “Social Capital, Innovation and Economic Growth”, 2015

Kurt R. Brekke, Chiara Canta, Odd Rune Straume, "Reference pricing with endogenous generic entry", 2015

Aguiar-Conraria, Luís, Pedro Brinca, Haukur Viðar Guðjónsson e Maria Joana Soares

"Optimum Currency Area and Business Cycle Synchronization Across U.S. States", 2015

Morozumi, Atsuyoshi, Francisco José Veiga e Linda Gonçalves Veiga, "Electoral effects on the composition of public spending and revenue: evidence from a large panel of countries", 2014 